\title{
Redox-Modulating Capacity and Antineoplastic Activity of Wastewater Obtained from the Distillation of the Essential Oils of Four Bulgarian Oil-Bearing Roses
}

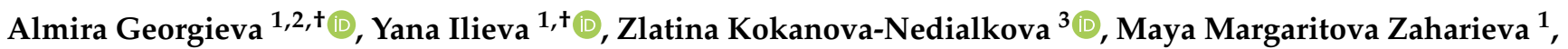 \\ Paraskev Nedialkov ${ }^{3}{ }^{(D}$, Ana Dobreva ${ }^{4}\left(\mathbb{D}\right.$, Alexander Kroumov ${ }^{1}$, Hristo Najdenski ${ }^{1}$ and Milka Mileva ${ }^{1, *(1)}$ \\ 1 The Stephan Angeloff Institute of Microbiology, Bulgarian Academy of Sciences, 26 Acad. G. Bonchev str., \\ 1113 Sofia, Bulgaria; al.georgieva@inb.bas.bg (A.G.); ilievayana@microbio.bas.bg (Y.I.); \\ zaharieva26@yahoo.com (M.M.Z.); adkrumov@gmail.com (A.K.); hnajdenski@abv.bg (H.N.) \\ 2 Institute of Neurobiology, Bulgarian Academy of Sciences, 23 Acad. G. Bonchev str., 1113 Sofia, Bulgaria \\ 3 Faculty of Pharmacy, Medical University of Sofia, 2 Dunav str., 1000 Sofia, Bulgaria; \\ zlatina.kokanova@pharmfac.musofia.bg (Z.K.-N.); pnediakov@pharmfac.musofia.bg (P.N.) \\ 4 Department of Aromatic and Medicinal Plants, Institute for Roses and Aromatic Plants, 49 Osvobojdenie \\ Blvd, 6100 Kazanlak, Bulgaria; anadobreva@abv.bg \\ * Correspondence: mileva@microbio.bas.bg; Tel.: +35-92-979-3185 \\ + Both authors contributed equally to this study.
}

Citation: Georgieva, A.; Ilieva, Y.; Kokanova-Nedialkova, Z.; Zaharieva, M.M.; Nedialkov, P.; Dobreva, A.; Kroumov, A.; Najdenski, H.; Mileva, M. Redox-Modulating Capacity and Antineoplastic Activity of Wastewater Obtained from the Distillation of the Essential Oils of Four Bulgarian Oil-Bearing Roses. Antioxidants 2021, 10, 1615. https://doi.org/10.3390/ antiox10101615

Academic Editor: Evangelos Zoidis

Received: 19 August 2021

Accepted: 4 October 2021

Published: 14 October 2021

Publisher's Note: MDPI stays neutral with regard to jurisdictional claims in published maps and institutional affiliations.

Copyright: (c) 2021 by the authors. Licensee MDPI, Basel, Switzerland. This article is an open access article distributed under the terms and conditions of the Creative Commons Attribution (CC BY) license (https:/ / creativecommons.org/licenses/by/ $4.0 /)$.
Abstract: The wastewater from the distillation of rose oils is discharged directly into the soil because it has a limited potential for future applications. The aim of the present study was to determine in vitro the chromatographic profile, redox-modulating capacity, and antineoplastic activity of wastewater obtained by distillation of essential oils from the Bulgarian Rosa alba L., Rosa damascena Mill., Rosa gallica L., and Rosa centifolia L. We applied UHPLC-HRMS for chromatographic analysis of rose wastewaters, studied their metal-chelating and Fe(III)-reducing ability, and performed MTT assay for the evaluation of cytotoxic potential against three tumorigenic (HEPG2-hepatocellular adenocarcinoma, A-375-malignant melanoma, A-431—non-melanoma epidermoid squamous skin carcinoma) and one non-tumorigenic human cell lines (HaCaT-immortalized keratinocytes). The median inhibitory concentrations $\left(\mathrm{IC}_{50}\right)$ were calculated with nonlinear modeling using the MAPLE ${ }^{\circledR}$ platform. The potential of the wastewaters to induce apoptosis was also examined. Mono-, di-, and acylated glycosides of quercetin and kaempferol, ellagic acid and its derivatives as main chemical components, and gallic acid and its derivatives—such as catechin and epicatechin-were identified. The redox-modulating capacity of the samples (TPTZ test) showed that all four wastewaters exhibited the properties of excellent heavy metal cleaners, but did not exert very strong cytotoxic effects. The lowest $\mathrm{IC}_{50}$ rate was provided in wastewater from $R$. centifolia $(34-35 \mu \mathrm{g} / \mathrm{mL}$ of gallic acid equivalents after a $72 \mathrm{~h}$ period for all cell lines). At 24 and 48 hours, the most resistant cell line was HEPG2, followed by HaCaT. After $72 \mathrm{~h}$ of exposure, the $\mathrm{IC}_{50}$ values were similar for tumor and normal cells. Still, $R$. damascena had a selectivity index over 2.0 regarding A-431 non-melanoma skin cancer cells, showing a good toxicological safety profile in addition to moderate activity- $\mathrm{IC}_{50}$ of $35 \mu \mathrm{g} / \mathrm{mL}$ polyphenols. The obtained results related to wastewaters acquired after the distillation of essential oils from the Bulgarian R. alba, R. damascena, R. gallica, and R. centifolia direct our attention to further studies for in-depth elucidation of their application as detoxifying agents under oxidative damage conditions in other experimental datasets.

Keywords: wastewater; UHPLC-HRMS analysis; antineoplastic activity; apoptosis induction; redox potential; nonlinear modeling

\section{Introduction}

It is very interesting that plants from the Rosaceae family have a great influence on world history and are among the most valuable oil-bearing plants. For centuries, different 
civilizations have used them to condiment the foods of kings and nobles, and applied them as embalming preservatives, perfumes, cosmetics, and medicines in various regions of the world [1-4]. In general, these plants have formed the basis of traditional medicine, and some of their derived substances have been utilized to treat different human diseases. Representatives of the genus Rosa deserve special attention; they are one of the most important groups of ornamental plants, and seen as a sign of inspiration, purity, love, happiness, and beauty $[2,4]$.

At the present time, the biggest producers of roses are countries such as Turkey, China, the countries of the former Soviet Union, Egypt, Morocco, and Bulgaria. In Bulgaria, the cultivation and processing of roses is a tradition and livelihood of a large part of the population and is very important for the agricultural economy of the country. Rosa damascena Mill., Rosa alba L., Rosa gallica L., and Rosa centifolia L. are the main species grown $[5,6]$.

In Bulgaria, the most popular method for the production of rose oil is a classical method of water-steam distillation, which leaves a water fraction as a remnant of the technological process [5,7]. It can be said that rose oil is more expensive than gold-more than $40 \mathrm{~kg}$ of rose inflorescences are used to produce one gram of oil [8].

The low yield of essential oil leads to the release of bulky waste-(1) used rose petals as a solid residue, as well as (2) wastewater (liquid residue) [9].

In this sense, the wastewaters (WWs) after rose oil distillation represent a serious environmental problem as pollutants, because they are discarded into drainage systems and rivers [4].

Already, at the beginning of this century, there was talk of recycling waste products from various industries. The valorization of plant materials and reuse of the potentially bioactive ingredients of these materials became the subject of numerous research investigations. Many novel approaches have been studied, including the extraction of polysaccharides from the biomass and the introduction of integrated methods for the more complete valorization of the rose waste byproducts. Due to insufficient data on their composition and biological activities, most of the methods for rose waste valorization still remain confined to the laboratory scale [9].

Rose WW, as a byproduct of hydrodistillation, is rich in water-soluble compounds such as polyphenols, glycosides, tannins, etc., so it can be used as a good, natural, inexpensive source of biologically active compounds and high-value products after more phytochemical, in vitro, and in vivo studies [4,10].

These compounds are the subject of a rather scarce but growing number of studies in terms of their biological potential. Sabahi et al. (2020) applied a cytotoxicity assay on HEP-G2 cells (human liver cancer cell line) exposed to different concentrations of $R$. damascena polyphenol-enriched fraction of WW for 24 and $48 \mathrm{~h}$. Significant toxicity at a concentration of $100 \mu \mathrm{g} / \mathrm{mL}$ and higher $(p<0.001)$ was reported in this cell line [10].

However, these kinds of results need to be validated in in vivo settings [11]. Different components of $R$. alba have been subject to various studies. Naikwade et al. (2009) reported a learning and memory-enhancing activity of $R$. alba; The authors indicated that aqueous extract of $R$. alba L. might be a useful memory-restorative agent for treating cognitive disorders such as Alzheimer's disease [12]. Polyphenols are among the most common secondary metabolites in the plant kingdom, involved in plants' pigmentation and their antioxidant defense system against UV light $[13,14]$. Chemically, polyphenols are largely planar molecules, and can be divided into several classes, e.g., phenolic acids, flavonoids, isoflavonoids, proanthocyanidins, anthocyanins, stilbenes, and lignans [15]. Polyphenols are known to have a wide range of biochemical activities, such as free radical scavenging and metal chelating, antioxidant, anticancer, anti-inflammatory, and antimutagenic activities, etc. (Table 1, also See Table S1 in Supplementary Materials).

Their activities are based on their ability to be excellent donors of hydrogen, which is accepted by reactive radicals to yield much less active radical and non-radical species [16]. In cells under normal physiological conditions, there is a balance between the rate of 
generation of ROS and their utilization by the cell's antioxidants $[17,18]$. The redox state of a cell determines its cellular functioning, and is usually kept within a narrow range under normal conditions [17]. The fine balance between the useful and detrimental effects of ROS is due to the metabolic reactions that use oxygen and constitute a very important part of protecting living organisms and maintaining "redox homeostasis" by controlling the redox regulation in vivo [19].

In the scientific literature, some approaches and suggestions for rose waste utilization have been described and sought, as well as suggestions for the reuse of the WWs, and the compounds with potentially beneficial effects contained therein. One such study provides evidence that phenolic compounds in water byproducts obtained after hydrodistillation of Taif rose (Rosa damascena trigintipetala Dieck) showed antioxidant activity [20].

Polyphenol-containing WW obtained after essential oil distillation of $R$. damascena was also proven to exert dose-dependent antiproliferative activity on immortalized human keratinocytes [4]. An interesting strategy for the processing of wastewater from the distillation of rose oil and the use of the contained substances was proposed by Rusanov et al. (2014); the authors, in the first stage in their research, determined the phytochemical profile of the wastewater from the distillation of rose oil from Rosa damascena Mill; next, they demonstrated that the RF20- (SP-207) and F (IV) subfractions isolated by them significantly inhibit cell proliferation and migration of HaCaT cells [21]. Reference is made in the scientific literature to the approaches developed for the study and valorization of wastewater-mainly from the distillation of Rosa damascena Mill. However, worldwide, rose oil production is based on several species: Rosa damascena Mill., Rosa gallica L., Rosa centifolia L., and Rosa alba L. [22,23]. The scarcity of studies on the composition and biological activities of the products derived from these roses, as well as the lack of data on their pharmacological and genotoxic potential, present a real challenge for scientists, and the opportunity to discover new substances with valuable qualities.

The aim of the present study was to determine in vitro the chromatographic profiles, redox-modulating capacity, and antineoplastic activity of WWs obtained via the distillation of essential oils from the Bulgarian Rosa alba, Rosa damascena, Rosa gallica, and Rosa centifolia. 


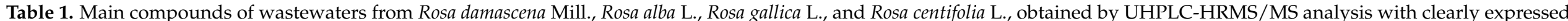
healing, antineoplastic, and antioxidant effects.

\begin{tabular}{|c|c|c|c|c|}
\hline Compounds & ${\text { Relative Content }(\%)^{1}}^{1}$ & Activity & \begin{tabular}{|l} 
Observations \\
\end{tabular} & References \\
\hline Gallic acid & $3.85-9.28$ & $\begin{array}{l}\text { Anticancer } \\
\text { Antioxidant }\end{array}$ & $\begin{array}{l}\text { Inhibits cell proliferation, reduces cell viability and induces apoptosis and ferroptosis } \\
\text { Free radical scavenger and metal chelator }\end{array}$ & $\begin{array}{c}{[24-34]} \\
{[28,29,31,33-35]}\end{array}$ \\
\hline Protocatechuic acid & $0.01-0.8$ & $\begin{array}{l}\text { Anticancer } \\
\text { Antioxidant }\end{array}$ & $\begin{array}{l}\text { Inhibits cancer cell metastasis } \\
\text { Induces cell cycle arrest and apoptosis through multiple signaling pathways from the } \\
\text { mitogen-activated protein kinase } \\
\text { Reduces }\left(\mathrm{Fe}^{3+}\right) \text {, reduces }\left(\mathrm{Cu}^{2+}\right) \text {, scavenges superoxide anion radicals and hydroxyl } \\
\text { radicals, chelates }\left(\mathrm{Fe}^{2+}\right) \text { and }\left(\mathrm{Cu}^{2+}\right)\end{array}$ & $\begin{array}{c}{[36]} \\
{[37,38]}\end{array}$ \\
\hline Corilagin & $0.23-0.45$ & $\begin{array}{l}\text { Anti-tumor } \\
\text { Antioxidant }\end{array}$ & $\begin{array}{l}\text { Affects the signaling pathways of tumor cells; induces apoptosis } \\
\text { Decreases malondialdehyde levels; restores the superoxide dismutase and glutathione } \\
\text { activity; elevates the Nrf2 and heme oxygenase-1 levels in rat cerebral ischemia }\end{array}$ & $\begin{array}{c}{[39-41]} \\
{[39]}\end{array}$ \\
\hline Proanthocyanin B2 & $0.01-0.75$ & Antineoplastic Antioxidant & $\begin{array}{l}\text { Inhibits proliferation and induces apoptosis of osteosarcoma cells } \\
\text { Reduces oxidative stress in human granulosa cells }\end{array}$ & $\begin{array}{c}{[42,43]} \\
{[44]}\end{array}$ \\
\hline Catechin & $0.4-5.16$ & $\begin{array}{l}\text { Anticancer } \\
\text { Antioxidant }\end{array}$ & $\begin{array}{c}\text { Inhibits cancer cell proliferation } \\
\text { Scavenges free radicals and retards extracellular matrix degradation induced by } \\
\text { ultraviolet (UV) radiation and pollution }\end{array}$ & $\begin{array}{l}{[45]} \\
{[45]}\end{array}$ \\
\hline Chlorogenic acid & $<0.01$ & $\begin{array}{l}\text { Anticancer } \\
\text { Antioxidant }\end{array}$ & $\begin{array}{c}\text { Serves as chemosensitizer in suppressing tumor growth through a metabolic pathway } \\
\text { Activates ERK } 1 / 2 \text { and inhibits proliferation of osteosarcoma cells } \\
\text { Takes part in the control of oxidative and inflammatory stress conditions; protects } \\
\text { DNA against oxidative damage }\end{array}$ & $\begin{array}{l}{[46,47]} \\
{[46,48]}\end{array}$ \\
\hline Ellagic acid & $10.98-16.88$ & $\begin{array}{l}\text { Anticancer } \\
\text { Antioxidant }\end{array}$ & $\begin{array}{c}\text { Inhibits the proliferation of prostate cancer cells; enhances the antitumor efficacy of } \\
\text { bevacizumab in an in vitro glioblastoma model } \\
\text { Radical scavenging activity_good scavenger of peroxynitrite }\end{array}$ & [51-60] \\
\hline Rutin & $<0.01$ & $\begin{array}{l}\text { Anticancer } \\
\text { Antioxidant }\end{array}$ & $\begin{array}{c}\text { Anticancer activity in combination with ionic liquids in renal cells; regulation of } \\
\text { different cellular signaling pathways } \\
\text { Inhibits lipid peroxidation, xanthine oxidase, } \mathrm{H}_{2} \mathrm{O}_{2} \text { generation, and lactate } \\
\text { dehydrogenase }\end{array}$ & $\begin{array}{l}{[61-67]} \\
{[65-68]}\end{array}$ \\
\hline Isoquercetin & $0.43-5.98$ & $\begin{array}{l}\text { Anticancer } \\
\text { Antioxidant }\end{array}$ & $\begin{array}{l}\text { Serves as adjunct therapy in patients with kidney cancer; inhibits bladder cancer cells; } \\
\text { antineoplastic activity; Radical scavenging effect }\end{array}$ & {$[61,69-73]$} \\
\hline Avicularin & $0.01-5.18$ & $\begin{array}{l}\text { Anticancer } \\
\text { Antioxidant }\end{array}$ & $\begin{array}{c}\text { Ameliorates human hepatocellular carcinoma via the regulation of } \\
\text { NF-kB/COX-2/PPAR- } \gamma \text { activities; antineoplastic activity; } \\
\text { DPPH and OH radical scavenging effect } \\
\text { Shows protective effect against oxidative stress induced by hydrogen peroxide by } \\
\text { inhibiting the formation of reactive oxygen species, reducing lipid peroxidation and } \\
\text { cell death }\end{array}$ & $\begin{array}{l}{[74-76]} \\
{[74,75]}\end{array}$ \\
\hline
\end{tabular}


Table 1. Cont.

Compounds

Relative Content (\%)

Activit

Quercetin

$0.16-1.25$

Anticancer

Antioxidan

Anticance

Kaempferol

$0.04-0.56$
Observations

the antiproliferative activity of cis-diamminedichloroplatinum(II); ribavirin and

quercetin synergistically downregulate signal transduction, and are cytotoxic in

human ovarian carcinoma cells; inhibits neck cancer; synergizes with

2-methoxyestradiol, inhibiting cell growth and inducing apoptosis in human prostate cancer cells; Scavenges intracellular free radicals

$$
\text { Anticancer potential on head and neck cancers; }
$$

regulates apoptosis in diverse cancer cell models; antineoplastic activity; inhibits experimental hepatocarcinogenesis

Inhibits lipid peroxidation and normalizes activities of antioxidant enzymes; radical scavenging effect

Inhibits lipid peroxida

\section{References}

$[77-81$

$[82-84$ 


\section{Materials and Methods}

\subsection{Preparation of Wastewater from the Industrial Cycle of Water-Steam Distillation of Rose Oil}

The WWs were collected after the distillation of rose flowers, as illustrated in Figure 1. The semi-industrial installation of the Institute for Roses was used. The process parameters were as follows: raw material $8-10 \mathrm{~kg}$; hydromodule 1:4; flow rate $16-20 \mathrm{~mL} / \mathrm{min}$; duration $150 \mathrm{~min}$. The WWs were sealed and stored in a cool place until the next stage of the investigations.

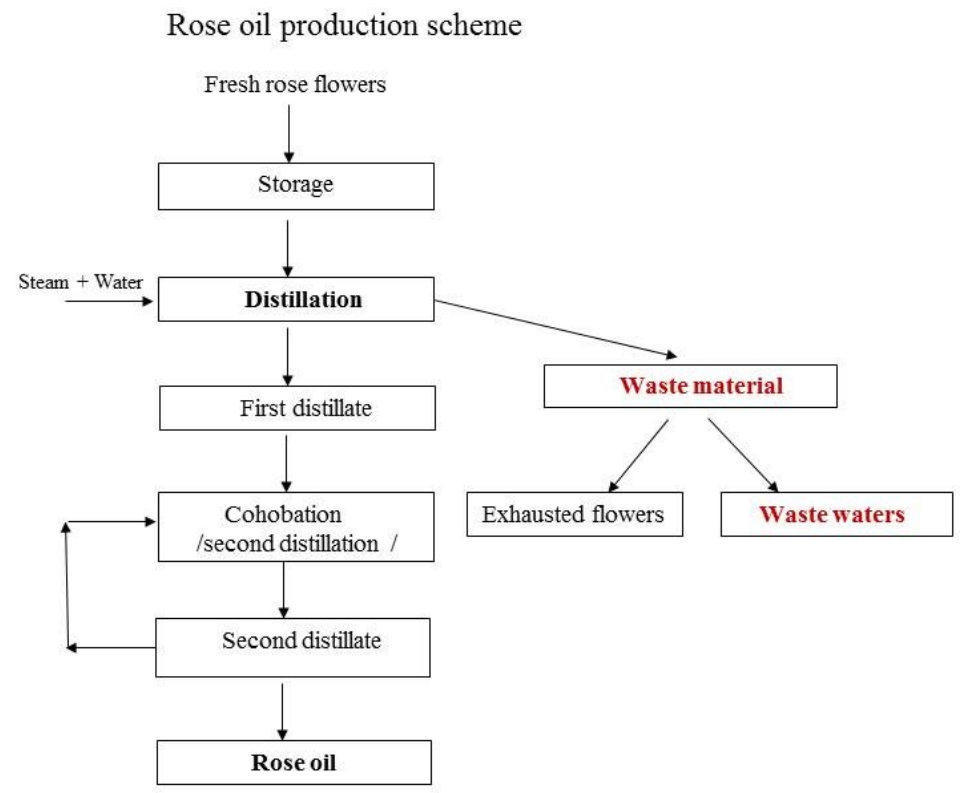

Figure 1. Rose oil production scheme and collection of wastewater material.

2.2. LC-MS of Wastewater of Rosa damascena Mill., Rosa alba L., Rosa gallica L., and Rosa centifolia L.

2.2.1. Sample Preparations

The samples of WWs resulting from the steam distillation of rose flowers were prepared as follows: One milliliter of each sample was centrifuged at 14,000 rpm, and was subjected to solid-phase extraction (SPE) on Strata ${ }^{\circledR}$ C18-E (55 $\mu \mathrm{m}, 70 \AA$, 200 mg, Phenomenex) cartridges, washed with distilled water and, finally, analytes were recovered with $6 \mathrm{~mL}$ methanol/water (80:20) mixtures. The final volume was adjusted to $10 \mathrm{~mL}$.

\subsubsection{Chromatographic Separation and Mass Spectrometric Conditions}

UHPLC-HRMS analysis was performed using a Thermo Scientific Dionex Ultimate 3000 RSLC (Germering, Germany) consisting of an SRD-3600 6-channel degasser, HPG3400RS high-pressure gradient pump, WPS-3000TRS autosampler, and TCC-3000RS column compartment coupled with a Thermo Scientific Q Exactive Plus (Bremen, Germany) mass spectrometer. UHPLC separations were performed on a Kromasil Eternity XT C18 column (AkzoNobel, Angered, Sweden) $(2.1 \times 100 \mathrm{~mm}, 1.8 \mu \mathrm{m})$ equipped with a SecurityGuard ULTRA UHPLC EVO C18 precolumn (Phenomenex, CA, USA) at $40^{\circ} \mathrm{C}$. Each chromatographic run was carried out with a binary mobile phase consisting of water containing $0.1 \%(v / v)$ formic acid (A) and acetonitrile along with $0.1 \%(v / v)$ formic acid (B). A gradient program was used as follows: 0-1 $\mathrm{min}, 5 \% \mathrm{~B} ; 1-25 \mathrm{~min}, 5-30 \% \mathrm{~B} ; 25-30 \mathrm{~min}, 30-40 \% \mathrm{~B}$; 30-32.5 $\mathrm{min}, 40-95 \% \mathrm{~B} ; 32.5-34.5 \mathrm{~min}, 95 \% \mathrm{~B}$. The flow rate was $0.3 \mathrm{~mL} . \mathrm{min}^{-1}$ and the sample injection volume was $2 \mu \mathrm{L}$. The system was conditioned for $4.5 \mathrm{~min}$ before injection. The operating conditions for the HESI source used in a negative ionization mode were as follows: $-2.5 \mathrm{kV}$ spray voltage, $320^{\circ} \mathrm{C}$ capillary and probe heater temperature, sheath gas flow rate of 38 a.u., auxiliary gas flow of 12 a.u. (a.u. refers to arbitrary values set by the Exactive Tune software), and S-Lens RF level of 50.00. Nitrogen was used for sample 
nebulization, and as the collision gas in HCD cells. Top5 was used for MS experiments, where in full MS mode the resolution, automatic gain control (AGC) target, maximum injection time (IT), and mass range were 70,000 (at m/z 200), 1e6, 80 ms, and m/z 100-1500, respectively, while ddMS2 conditions were set to resolution 17,500 (at m/z 200), AGC target 1e5, max. IT $50 \mathrm{~ms}$, isolation window $2.0 \mathrm{~m} / \mathrm{z}$, and stepped normalized collision energy (NCE) of 20, 40, and 70. Xcalibur (Thermo Fisher Scientific) ver. 4.0 and FreeStyle (Thermo Fisher Scientific) ver. 1.8 SP1 were used for data acquisition and processing, respectively.

\subsubsection{Determination of Tannins, Flavonoids, and Total Polyphenols}

The quantity of tannins and flavonoids was established according to the European Pharmacopoeia method [89,90], and expressed as $\mathrm{mg} / \mathrm{mL}$ of pyrogallol equivalents for tannins, and $\mathrm{mg} / \mathrm{mL}$ of hyperoside equivalents for flavonoids in rose WW. The FolinCiocalteu method [91], with some modifications, was used for measurement of the total phenolic content. The results were calculated as gallic acid equivalents per $1 \mathrm{~mL}$ of WW (mg GAE/ mL WW), based on a standard curve of gallic acid.

\subsection{Cell Lines and Culture Conditions}

In the present work, three human tumor cell lines were used-HEP-G2 (hepatocellular adenocarcinoma; the cell line retains a lot of hepatocyte-related features in the proteome, and a high degree of morphological and functional differentiation) [92-96], and the skin cancer lines A-375 (malignant melanoma) and A-431 (non-melanoma epidermoid squamous skin carcinoma). As a model for non-tumorigenic "normal and healthy" cells, the human skin cell line HaCaT (immortalized keratinocytes) was used. The skin cell lines were purchased from CLS Cell Lines Service (GmbH, Eppelheim, Germany), and HEP-G2 cells were obtained from DSMZ (Deutsche Sammlung von Mikroorganismen und Zellkulturen, German Collection of Microorganisms and Cell Cultures GmbH, Braunschweig, Germany). Maintenance of cells followed the protocols described previously in [97].

\subsection{Cell Viability Assay}

MTT assay was executed according to Annex C, ISO 10993-5 (ISO 10993-5:2009) for the evaluation of cytotoxic activity, as previously described [97], but there was exposure after treatment for 24 and $48 \mathrm{~h}$ in addition to the incubation for $72 \mathrm{~h}$.

\subsection{Mathematical Modelling of Cytotoxic Effects and Redox-Modulating Capacities of Wastewaters}

The median individual effects (median inhibitory concentrations, $\mathrm{IC}_{50}$ ) of the WWs obtained from the four rose species were calculated by adapting an algorithm published elsewhere [98]. The theory of Chou and Talalay was applied, with some modifications [99]. Specifically, we coded a non-linear identification procedure in the MAPLE ${ }^{\circledR}$ software based on the weighted least squares statistical criterion as an objective function of the search. To minimize the sum of weighted squares and to find the estimates of constant values, we applied a numerical optimization algorithm. The median dose model was used to obtain the " $I C_{50}$ " and " $m$ ", as presented in Equation (1):

$$
\frac{F_{a}}{F_{u}}=\left(\frac{\text { Dose }}{D_{m}}\right)^{m}
$$

where $F_{a}$ stands for affected fraction; $F_{u}$ stands for unaffected fraction $\left(1-F_{a}\right)=F_{u}$; Dose is the applied drug concentration; $D_{m}$ represents the median-effect dose (in our case $\left.D_{m}=I C_{50}\right)$, and $m$ is the slope of the median-effect plot. Quantitative evaluation of effects $\left(\mathrm{IC}_{50}\right)$ was supported by the values of the correlation coefficient $\mathrm{R}$ obtained for every experimental dataset. The quantitative evaluation of the redox-modulating capacities of the four wastewaters was performed using the same mathematical model. The half-maximal effective concentrations were presented as $\mathrm{EC}_{50}$ on the graphs. 


\subsection{Detection of Apoptosis with Annexin $V$}

In early apoptotic cells, the membrane phospholipid phosphatidylserine (PS) is translocated from the inner to the outer leaflet of the plasma membrane, thereby exposing PS to the external cellular environment. Annexin $\mathrm{V}$ as a phospholipid-binding protein has a high affinity for PS, and binds to cells with exposed PS. Annexin V conjugated to the fluorochrome FITC was used in this assay to assess apoptosis. Cell suspensions $(50 \mu \mathrm{L})$ of the same density as for the MTTassay were seeded in the wells of a 96-well microplate for fluorescence-based assays, followed by standard $24 \mathrm{~h}$ incubation at $37^{\circ} \mathrm{C}$. Then, cells were treated with WWs from $R$. damascena and $R$. centifolia - doses of $1 / 2 \mathrm{IC}_{50}$ or $\mathrm{IC}_{50}$ (for $72 \mathrm{~h}$ ) for the tumor cell lines, or with the $72 \mathrm{~h} \mathrm{IC}_{50}$ dose of the skin cancer lines for $\mathrm{HaCaT}$ and HEP-G2 and exposed for $48 \mathrm{~h}$. Then, cells were washed twice with cold PBS and covered with Annexin V binding buffer (component no. 51-66121E) $\left(1 \mathrm{~mL}\right.$ per $1 \times 10^{6}$ cells were used) and FITC Annexin V (component no. 51-65874X) (5 $\mu \mathrm{L}$ for every $100 \mu \mathrm{L}$ buffer was used). Both components were purchased from BD Biosciences (Franklin Lakes, NJ, USA). Unstained controls remained for blanks. Plates were incubated for $15 \mathrm{~min}$ at $25^{\circ} \mathrm{C}$ in the dark, and the volume in the wells was also $5 \times$ diluted with binding buffer. Plates were read using a fluorometer (Bio-Tek Instruments Inc., Winooski, VT, USA) at 485/528 nm (excitation/emission).

\subsection{Caspase Activity Assay}

The activity of caspase- 3 and -7 was evaluated after treatment of the four cell lines with WWs from R. damascena and R. centifolia for $48 \mathrm{~h}$. Briefly, cell suspensions were seeded in the same quantity and density as for the MTTassay. After $24 \mathrm{~h}$ of incubation, cells were treated with concentrations ranging between $1 / 2 \mathrm{IC}_{50}$ and $1.5 \mathrm{IC}_{50}$ for $48 \mathrm{~h}$. The results were analyzed in 96-well microplates using the Apo-Glo ${ }^{\mathrm{TM}}$ assay (Promega, Germany) according to the manufacturer's recommendations. The luminescence was measured using a luminometer (Bio-Tek Instruments Inc., VT, USA) and expressed as percentage of the untreated control.

\subsection{Detection of Intracellular Reactive Oxygen Species Generation}

The generation of reactive oxygen species (ROS) was determined using the Fluorometric Intracellular ROS Kit (\#MAK143, Sigma ${ }^{\circledR}$ Life Science, Darmstadt, Germany), following the manufacturer's protocol. Cells were prepared in the same way and in the same density as for the previous assays. The results were measured in a 96-well plate (half area, transparent bottom, black walls) after $6 \mathrm{~h}$ of exposure to WWs from $R$. damascena and $R$. centifolia. The fluorometric reaction product proportional to the amount of ROS present was measured at $\lambda_{\mathrm{ex}}=490 / \lambda_{\mathrm{em}}=520 \mathrm{~nm}$ (Bio-Tek Instruments Inc., Winooski, VT, USA).

\subsection{Induction of Cytochrome P450 3A4 (CYP3A4) In Vitro}

The concentration of human CYP3A4 (in $\mathrm{ng} / \mathrm{mL}$ ) in HaCaT and HEP-G2 cell lines after $24 \mathrm{~h}$ of exposure to doses of $\mathrm{IC}_{50}$ and $2 \mathrm{IC}_{50}$ (for $72 \mathrm{~h}$ ) of the most promising WWs (from R. damascena and R. centifolia) was determined using the Human Cytochrome P450 3A4 (CYP3A4) ELISA Kit (Catalog No: DL-CYP3A4-Hu, DLdevelop, Kelowna, BC, Canada), according to the manufacturer's instructions. This test is a sandwich enzyme immunoassay based on the binding of CYP3A4 in standards and samples to a biotin-conjugated antibody preparation specific to CYP3A4. The binding of biotin to avidin conjugated to horseradish peroxidase ensures that after the addition of TMB substrate solution, only those microtiter plate wells that contain CYP3A4, biotin-conjugated antibody, and enzyme-conjugated avidin exhibit a change in color. The reaction is terminated by the addition of sulfuric acid solution, and the plate is read at $450 \mathrm{~nm}$. The concentration of CYP3A4 is determined by comparing the O.D. of the samples to the standard curve. 


\subsection{Redox-Modulating Capacity of Wastewater from the Industrial Cycle of Water-Steam Distillation of Rose Oil}

\subsubsection{Ferric-Reducing Antioxidant Power (FRAP)}

FRAP assay was performed as described in [100], with light modifications. This method is based on the reduction of $\mathrm{Fe}(\mathrm{III})$ ions to $\mathrm{Fe}(\mathrm{II})$ at low $\mathrm{pH}$, if the sample contains reductant (antioxidant). Thereby, the colorless complex Fe(III)-(TPTZ) 2,3,5-triphenyltetrazolium chloride turns into the blue-stained Fe(II)-TPZ complex. The analysis was performed as follows: Solutions: (1) $0.03 \mathrm{M}$ acetate buffer, pH 3.6; (2) $1 \mathrm{mM}$ TPTZ (2,4,6-tripyridyl-s-triazine, in $40 \mathrm{mM} \mathrm{HCl}$ ); (3) $1.5 \mathrm{mM} \mathrm{FeCl} 3 \cdot 6 \mathrm{H}_{2} \mathrm{O}$. The thus-prepared solutions were mixed in the following ratio: 10 parts $0.03 \mathrm{M}$ acetate buffer (1): 1 part $1 \mathrm{mM}$ TPTZ (2): 20 parts $1.5 \mathrm{mM} \mathrm{FeCl}_{3}$ (3). To $1.5 \mathrm{~mL}$ of the reaction mixture, $50 \mu \mathrm{L}$ of the sample was added; blank-reaction mixture $+50 \mu \mathrm{L}$ of $\mathrm{H}_{2} \mathrm{O}$ was used instead of the sample. Incubation for $4 \mathrm{~min}$. at $37^{\circ} \mathrm{C}$ followed. Absorption was measured at $593 \mathrm{~nm}$. The results were expressed as mmol Trolox equivalents per $\mathrm{mL}$ of $\mathrm{WW}$.

\subsubsection{Cupric-Reducing Antioxidant Capacity (CUPRAC) Assay}

The assay described in [101] was adapted. The CUPRAC reaction of $\mathrm{Cu}(\mathrm{II})$-neocuproine complex with antioxidants results in a change from blue to yellow/orange due to $\mathrm{Cu}(\mathrm{I})$-neocuproine chelate $(\lambda \max =450 \mathrm{~nm})$. Solutions: (1) $10 \mathrm{mM} \mathrm{CuCl}_{2}$ in $\mathrm{dd}_{2} \mathrm{O}$; (2) $1.0 \mathrm{M}$ ammonium acetate buffer; $\mathrm{pH} 7$; (3) $7.5 \mathrm{mM}$ neocuproine (NC) in $96 \%$ ethanol. The common reaction mixture was prepared in the following arrangement: 1 part $\mathrm{Cu}$ (II) (1): 1 part NC (3): 1 part buffer (2). In Eppendorf safe-lock tubes $\mathrm{X} \mathrm{mL}$ of each tested substance was added, and the volume was brought to $0.550 \mathrm{~mL}$ by adding $\mathrm{H}_{2} \mathrm{O}$. Next, $1.5 \mathrm{~mL}$ of the common reaction mixture was added. After incubation at $50^{\circ} \mathrm{C}$ for $20 \mathrm{~min}$, the absorption was read at $450 \mathrm{~nm}$ against a blank sample $(1.5 \mathrm{~mL}$ of common reaction mixture was added to $0.550 \mathrm{~mL}$ of $\mathrm{H}_{2} \mathrm{O}$ ). Standard curves were prepared with Trolox in different concentrations, ranging from $0.1 \mathrm{mmol}$ to $1 \mathrm{mmol}$, and results were expressed as mmol Trolox equivalents per $1 \mathrm{~mL}$ of WW.

\subsubsection{Fe (II)-Chelating Assay}

Iron(II) ions react with ferrozine to form a pink complex with a maximum absorption at $562 \mathrm{~nm}$. Therefore, the presence of a chelating agent in the reaction medium will reduce the measured absorbance. Procedure: $0.2 \mathrm{~mL}$ of sample solution, $0.74 \mathrm{~mL}$ of $0.1 \mathrm{M}$ sodium/acetate buffer ( $\mathrm{pH} 5.23$ ), and $0.02 \mathrm{~mL}$ of $2 \mathrm{mM}$ solution of ferrous sulfate in $0.2 \mathrm{M}$ hydrochloric acid were mixed for 10-15 s. Then, $0.04 \mathrm{~mL}$ of $5 \mathrm{mM}$ ferrozine solution (mw: $492.46 \mathrm{~g}$ ) was added, and the absorbance was measured after keeping it in the dark for $10 \mathrm{~min}$. The Fe(II)-chelating capacity of the tested substance was determined using the following formula:

$$
\text { Activity }(\%)=100(\mathrm{Ac}-\mathrm{As}) /(\mathrm{Ac}) \text {, }
$$

where Ac is the absorbance of the blank probe, containing $200 \mu \mathrm{L}$ of sodium/acetate buffer instead of the sample, while As is the absorbance of the sample solution [102].

\subsection{Statistical Analysis}

The experiments for determination of the median inhibitory concentrations were performed three times, wherein each concentration was repeated four times. Samples and standards (when used) for the tests for the induction of cytochrome P450 3A4, as well as the Annexin V, caspase-3/7, and ROS tests, were carried out in duplicate. $\mathrm{IC}_{50}$ values expressed as $\mu \mathrm{g} / \mathrm{mL}$ of polyphenols were calculated based on the determined $\mathrm{IC}_{50}$ as a percentage of $\mathrm{WW}(\mathrm{v} / \mathrm{v})$ and the previously measured contents of polyphenols $(\mathrm{mg} / \mathrm{mL})$ of each WW. The selectivity index (SI) represents the $\mathrm{IC}_{50}$ value of an agent for the nontumorigenic cell lines HaCaT or HEP-G2 (though a cancer line, the latter retains numerous hepatocyte-related features) divided by the $\mathrm{IC}_{50}$ value of a tumor cell line or the average $\mathrm{IC}_{50}$ value of several tumor lines. The statistical evaluation of the data and the comparison between the treated groups were performed via two-way ANOVA using the GraphPad 
Prism software (version 6.01 for Windows, GraphPad Software Inc., San Diego, CA, USA). Statistical processing set $p \leq 0.05$ as the significance level.

\section{Results}

\subsection{Chromatographic Profile and Content of Tannins, Flavonoids, and Total Polyphenols}

Chromatographic analysis showed that the WWs from the four roses contained many of the same ingredients—gallic acid, glucogallin, catechin, chlorogenic acid, brevifolincarboxylic acid, epicatechin, ellagic acid, hyperoside, miquelianin, avicularin, kaempferol, and their derivatives (see Table S1 in Supplementary Materials). They exhibit very good biological activities, such as antineoplastic, antitumor, radical scavenging, and redox-modulating effects (Table 1).

The data from the quantitative analysis of tannins, flavonoids, and total polyphenols are shown in Table 2. The highest level of tannins was found in WW from $R$. centifolia $(2.47 \pm 0.05 \mathrm{mg} / \mathrm{mL})$, followed by R. alba $(2.16 \pm 0.35 \mathrm{mg} / \mathrm{mL})$. The total flavonoid content expressed as hyperoside varied from 0.37 to $1.14 \mathrm{mg} / \mathrm{mL}$ in the rose WWs. R. damascena and R. alba WWs demonstrated the highest quantities of flavonoids $(1.14 \pm 0.01 \mathrm{mg} / \mathrm{mL}$ and $1.00 \pm 0.01 \mathrm{mg} / \mathrm{mL}$, respectively). The content of total polyphenols was highest in R. centifolia $(7.8 \mathrm{mg} / \mathrm{mL}$ GAE), and the lowest was the WW from R. damascena (7.2. $\mathrm{mg} / \mathrm{mL}$ GAE).

Table 2. Content of tannins, flavonoids, and total polyphenols in wastewaters from the tested roses.

\begin{tabular}{cccc}
\hline Wastewater & 2 Tannins $(\mathbf{m g} / \mathbf{m L})$ & $\begin{array}{c}\mathbf{1} \text { Total Flavonoids } \\
\mathbf{( m g / m L )}\end{array}$ & $\begin{array}{c}\mathbf{3}^{\mathbf{T}} \text { Total Polyphenols } \\
\mathbf{( m g / m L )}\end{array}$ \\
\hline Rosa damascena Mill. & $1.61 \pm 0.05$ & $1.14 \pm 0.01$ & $7.2 \pm 0.2$ \\
Rosa alba L. & $2.16 \pm 0.35$ & $1.00 \pm 0.01$ & $7.6 \pm 0.3$ \\
Rosa gallica L. & $1.51 \pm 0.09$ & $0.37 \pm 0.02$ & $7.7 \pm 0.03$ \\
Rosa centifolia L. & $2.47 \pm 0.05$ & $0.61 \pm 0.04$ & $7.8 \pm 0.22$ \\
\hline${ }^{1}$ Calculated as hyperoside; ${ }^{2}$ calculated as pyrogallol; ${ }^{3}$ calculated as gallic acid equivalents $(\mu \mathrm{g} \mathrm{GAE} / \mathrm{mL})$.
\end{tabular}

\subsection{Cytotoxicity of Wastewaters}

WWs from the four roses did not exert significant cytotoxic effects on the chosen human cancer and normal cell lines (Table 3, Figure 2). The median inhibitory concentrations of the WWs are presented as volumetric concentrations (\%) in Table 3. In addition, the corresponding total polyphenolic contents determined as gallic acid equivalents (Table 2) are given in brackets. The lowest median inhibitory concentration $\left(\mathrm{IC}_{50}\right)$ was of $R$. centifolia (34-35 $\mu \mathrm{g}$ $\mathrm{GAE} / \mathrm{mL}$ ) for $72 \mathrm{~h}$ for all cell lines. This is not an outstanding effect according to the National Cancer Institute guidelines, which determine that a promising extract is one with an $\mathrm{IC}_{50}<20 \mu \mathrm{g} / \mathrm{mL}$ [103]. The highest $\mathrm{IC}_{50}$ value for the same incubation time was $83 \mu \mathrm{g}$ $\mathrm{GAE} / \mathrm{mL}$ for $R$. damascena and $\mathrm{HaCaT}$ cells. As usual, $\mathrm{IC}_{50}$ values became lower with increasing time of exposure, and for $24 \mathrm{~h}$ they varied between 54 and $261 \mu \mathrm{g} \mathrm{GAE} / \mathrm{mL}$. It is important to note that for the $24 \mathrm{~h}$ exposure, invariably, the most resistant cell line (i.e., with the highest $\mathrm{IC}_{50}$ values) was HEP-G2, followed by HaCaT, A-431, and A-375 (Supplementary Table S2). For $48 \mathrm{~h}$, this pattern was maintained, with slight exceptions (Supplementary Table S3), while the $72 \mathrm{~h}$ exposure time equalized the differences to a great extent.

Table 3. Median inhibitory concentrations of wastewaters obtained from different rose species in non-tumorigenic and tumor cell lines after $72 \mathrm{~h}$ of incubation.

\begin{tabular}{|c|c|c|c|c|c|}
\hline Cell Line & Model Parameters & $\begin{array}{l}\text { WW from } \\
\text { R. centifolia } \mathrm{L} \text {. }\end{array}$ & $\begin{array}{l}\text { WW from } \\
\text { R. gallica } \mathrm{L} \text {. }\end{array}$ & $\begin{array}{c}\text { WW from } \\
\text { R. damascene Mill. }\end{array}$ & WW from R. alba $\mathrm{L}$. \\
\hline \multirow{3}{*}{ HEP-G2 } & HillSlope & 0.795 & 1.115 & 0.988 & 1.017 \\
\hline & $\mathrm{IC}_{50}$ & $\begin{array}{c}0.45 \% * \\
\left(=35.1 \mu \mathrm{g} \mathrm{GAE}^{* *} / \mathrm{mL}\right)\end{array}$ & $\begin{array}{c}1.01 \% \\
(=77.77 \mu \mathrm{g} \mathrm{GAE} / \mathrm{mL})\end{array}$ & $\begin{array}{c}1.049 \% \\
(=75.53 \mu \mathrm{g} \mathrm{GAE} / \mathrm{mL})\end{array}$ & $\begin{array}{c}0.622 \% \\
(=47.27 \mu \mathrm{g} \mathrm{GAE} / \mathrm{mL})\end{array}$ \\
\hline & $\begin{array}{l}\mathrm{R} \text { (correlation } \\
\text { coefficient) }\end{array}$ & 0.997 & 0.994 & 0.993 & 0.997 \\
\hline
\end{tabular}


Table 3. Cont

\begin{tabular}{|c|c|c|c|c|c|}
\hline Cell Line & Model Parameters & $\begin{array}{c}\text { WW from } \\
\text { R. centifolia L. }\end{array}$ & $\begin{array}{l}\text { WW from } \\
\text { R. gallica L. }\end{array}$ & $\begin{array}{c}\text { WW from } \\
\text { R. damascene Mill. }\end{array}$ & WW from R. alba L. \\
\hline \multirow{3}{*}{$\mathrm{HaCaT}$} & HillSlope & 1.13 & 1.16 & 0.954 & 0.81 \\
\hline & $\mathrm{IC}_{50}$ & $\begin{array}{c}0.435 \% \\
(=33.93 \mu \mathrm{g} \text { GAE } / \mathrm{mL})\end{array}$ & $\begin{array}{c}0.879 \% \\
(=67.68 \mu \mathrm{g} \mathrm{GAE} / \mathrm{mL})\end{array}$ & $\begin{array}{c}1.15 \% \\
(=82.8 \mu \mathrm{g} \mathrm{GAE} / \mathrm{mL})\end{array}$ & $\begin{array}{c}0.616 \% \\
(=46.82 \mu \mathrm{g} \mathrm{GAE} / \mathrm{mL})\end{array}$ \\
\hline & $\begin{array}{l}\mathrm{R} \text { (correlation } \\
\text { coefficient) }\end{array}$ & 0.966 & 0.966 & 0.985 & 0.982 \\
\hline \multirow{3}{*}{ A-375 } & HillSlope & 1.582 & 1.576 & 1.976 & 1.15 \\
\hline & $\mathrm{IC}_{50}$ & $\begin{array}{c}0.455 \% \\
(=35.49 \mu \mathrm{g} \mathrm{GAE} / \mathrm{mL})\end{array}$ & $\begin{array}{c}0.729 \% \\
(=56.13 \mu \mathrm{g} \mathrm{GAE} / \mathrm{mL})\end{array}$ & $\begin{array}{c}0.857 \% \\
(=61.7 \mu \mathrm{g} \mathrm{GAE} / \mathrm{mL})\end{array}$ & $\begin{array}{c}0.835 \% \\
(=63.46 \mu \mathrm{g} \mathrm{GAE} / \mathrm{mL})\end{array}$ \\
\hline & $\begin{array}{l}\mathrm{R} \text { (correlation } \\
\text { coefficient) }\end{array}$ & 0.979 & 0.985 & 0.996 & 0.99 \\
\hline \multirow{3}{*}{ A-431 } & HillSlope & 1.062 & 0.991 & 0.893 & 1.01 \\
\hline & $\mathrm{IC}_{50}$ & $\begin{array}{c}0.435 \% \\
(=33.93 \mu \mathrm{g} \text { GAE } / \mathrm{mL})\end{array}$ & $\begin{array}{c}0.672 \% \\
(=51.74 \mu \mathrm{g} \text { GAE } / \mathrm{mL})\end{array}$ & $\begin{array}{c}0.485 \% \\
(=34.92 \mu \mathrm{g} \text { GAE } / \mathrm{mL})\end{array}$ & $\begin{array}{c}0.53 \% \\
(=40.28 \mu \mathrm{g} \mathrm{GAE} / \mathrm{mL})\end{array}$ \\
\hline & $\begin{array}{l}\mathrm{R} \text { (correlation } \\
\text { coefficient) }\end{array}$ & 0.987 & 0.982 & 0.985 & 0.99 \\
\hline
\end{tabular}

Legend: HEP-G2: liver adenocarcinoma (stage I); HaCaT: normal human keratinocytes; A-375: malignant melanoma; A-431: epidermoid carcinoma of the skin; HillSlope: slope factor or Hill slope, unitless; $\mathrm{IC}_{50}$ : median inhibitory concentration; *: volumetric concentration in $(\%) ;{ }^{* *}(\mu \mathrm{g} \mathrm{GAE} / \mathrm{mL})=$ concentration of total polyphenols determined as gallic acid equivalents.

Therefore, the WWs at $72 \mathrm{~h}$ already did not have much selectivity towards cancer cell lines. The best selectivity at that incubation time was observed for $R$. damascena, which was the only WW that had a selectivity index of over 2 towards the non-melanoma skin cancer cells A-431 (compared to both HaCaT and HEP-G2 cells) (Table 4). An SI over 2 or 3 is considered a promising value in practice. Therefore, the WW from $R$. damascena has a moderate anticancer activity on non-melanoma skin cancer ( $\mathrm{IC}_{50}$ of $35 \mu \mathrm{g} / \mathrm{mL}$ polyphenols), and a good toxicological safety profile.

Table 4. Comparison of the cytotoxicity of wastewaters obtained from four different rose species on non-tumorigenic and tumorigenic cell lines, based on selectivity index values.

\begin{tabular}{|c|c|c|}
\hline Rosa spp. & Cytotoxicity Based on $\mathrm{IC}_{50}$ Values & SI Values \\
\hline R. centifolia $\mathrm{L}$. & $\mathrm{A}-431^{*}=\mathrm{HaCaT}^{*}>\mathrm{HEP}-\mathrm{G} 2>\mathrm{A}-375^{* *}$ & $\begin{aligned} \mathrm{SI}_{\mathrm{HaCaT} / \mathrm{A}-375} & =0.96 \\
\mathrm{SI}_{\mathrm{HaCaT} / \mathrm{A}-431} & =1.00 \\
\mathrm{SI}_{\mathrm{HEP}-\mathrm{G} 2 / \mathrm{A}-375} & =0.99 \\
\mathrm{SI}_{\mathrm{HEP}-\mathrm{G} 2 / \mathrm{A}-431} & =1.03\end{aligned}$ \\
\hline R. gallica L. & A-431 * > A-375 > HaCaT > HEP-G2 ** & $\begin{aligned} \mathrm{SI}_{\mathrm{HaCaT} / \mathrm{A}-375} & =1.21 \\
\mathrm{SI}_{\mathrm{HaCaT} / \mathrm{A}-431} & =1.31 \\
\mathrm{SI}_{\mathrm{HEP}-\mathrm{G} 2 / \mathrm{A}-375} & =1.39 \\
\mathrm{SI}_{\mathrm{HEP}-\mathrm{G} 2} / \mathrm{A}-431 & =1.50\end{aligned}$ \\
\hline R. damascena Mill. & A-431 * $>$ A-375 $>$ HEP-G2 $>$ HaCaT $* *$ & $\begin{aligned} \mathrm{SI}_{\mathrm{HaCaT} / \mathrm{A}-375} & =1.34 \\
\mathrm{SI}_{\mathrm{HaCaT} / \mathrm{A}-431} & =2.37 \\
\mathrm{SI}_{\mathrm{HEP}-\mathrm{G} 2 / \mathrm{A}-375} & =1.22 \\
\mathrm{SI}_{\mathrm{HEP}-\mathrm{G} 2} / \mathrm{A}-431 & =2.16\end{aligned}$ \\
\hline R. alba L. & A-431* > HaCaT > HEP-G2 > A-375 ** & $\begin{aligned} \mathrm{SI}_{\mathrm{HaCaT} / \mathrm{A}-375} & =0.74 \\
\mathrm{SI}_{\mathrm{HaCaT} / \mathrm{A}-431} & =1.16 \\
\mathrm{SI}_{\mathrm{HEP}-\mathrm{G} 2 / \mathrm{A}-375} & =0.74 \\
\mathrm{SI}_{\mathrm{HEP}-\mathrm{G} 2} / \mathrm{A}-431 & =1.17\end{aligned}$ \\
\hline
\end{tabular}

Legend: *: most sensitive cell line; **: least sensitive cell line; SI: selectivity index. 

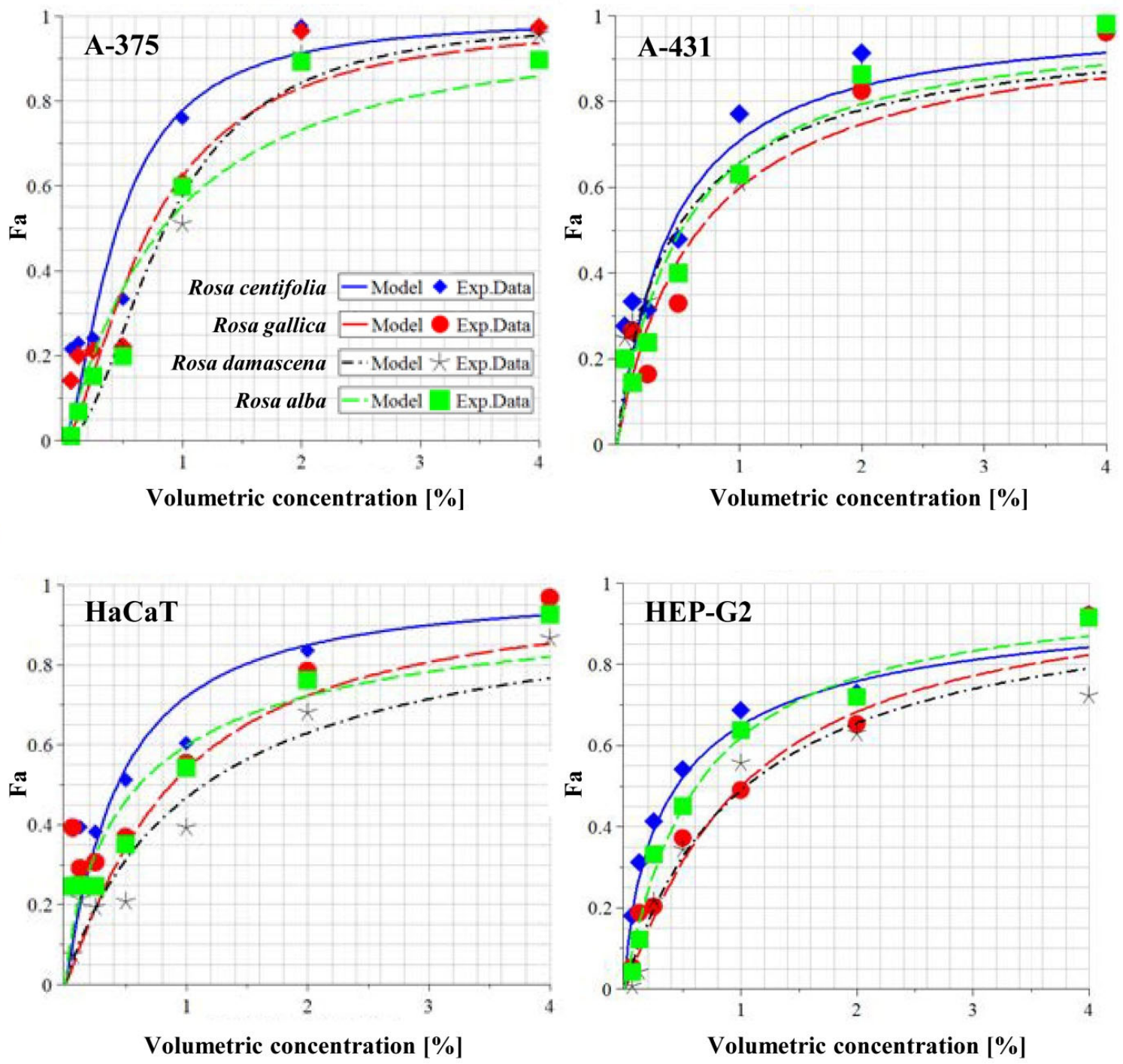

Figure 2. Cytotoxic activity of wastewaters from Rosa spp. on non-tumorigenic and tumorigenic cell lines—curve model. Legend: HEP-G2: liver adenocarcinoma (stage I); HaCaT: normal human keratinocytes; A-375: malignant melanoma; A-431: epidermoid carcinoma of the skin; Fa: antiproliferative effect (expressed as fraction of the untreated control). The curves describing the experimental data are presented on the plots with different types of lines and colors. The experimental data are presented as points with different shapes and colors corresponding to the color of the respective curve.

\subsection{Detection of Apoptosis by Annexin V and Caspase 3/7 Activity}

As we can see from the results presented in Figure 3, the WWs from $R$. damascena and $R$. centifolia induced apoptosis in all cell lines except for HEP-G2, judging by the rise in O.D values of Annexin-V-treated samples in comparison to controls. Apoptosis was induced to different extents in the A-375, A-431, and $\mathrm{HaCaT}$ cell lines, the most pronounced effect being in A-431 cells. Caspases cause most of the visible changes that characterize apoptotic cell death [104]. In parallel, a slight induction of caspase-3/7 was observed in the tumorigenic A-375 and A-431 cells, in contrast to the non-tumorigenic HaCaT and HEPG2 cells. The concentrations applied in the non-tumorigenic cell lines represent the $\mathrm{IC}_{50}$ values estimated for the tumorigenic cells. In this way, we compare the effects of the same concentrations in both cell types. The activation of caspase- $3 / 7$ was more pronounced in A-375 cells than in A-431. No significant changes in the caspase-3/7 activity were observed in HaCaT and HEP-G2 cells. 

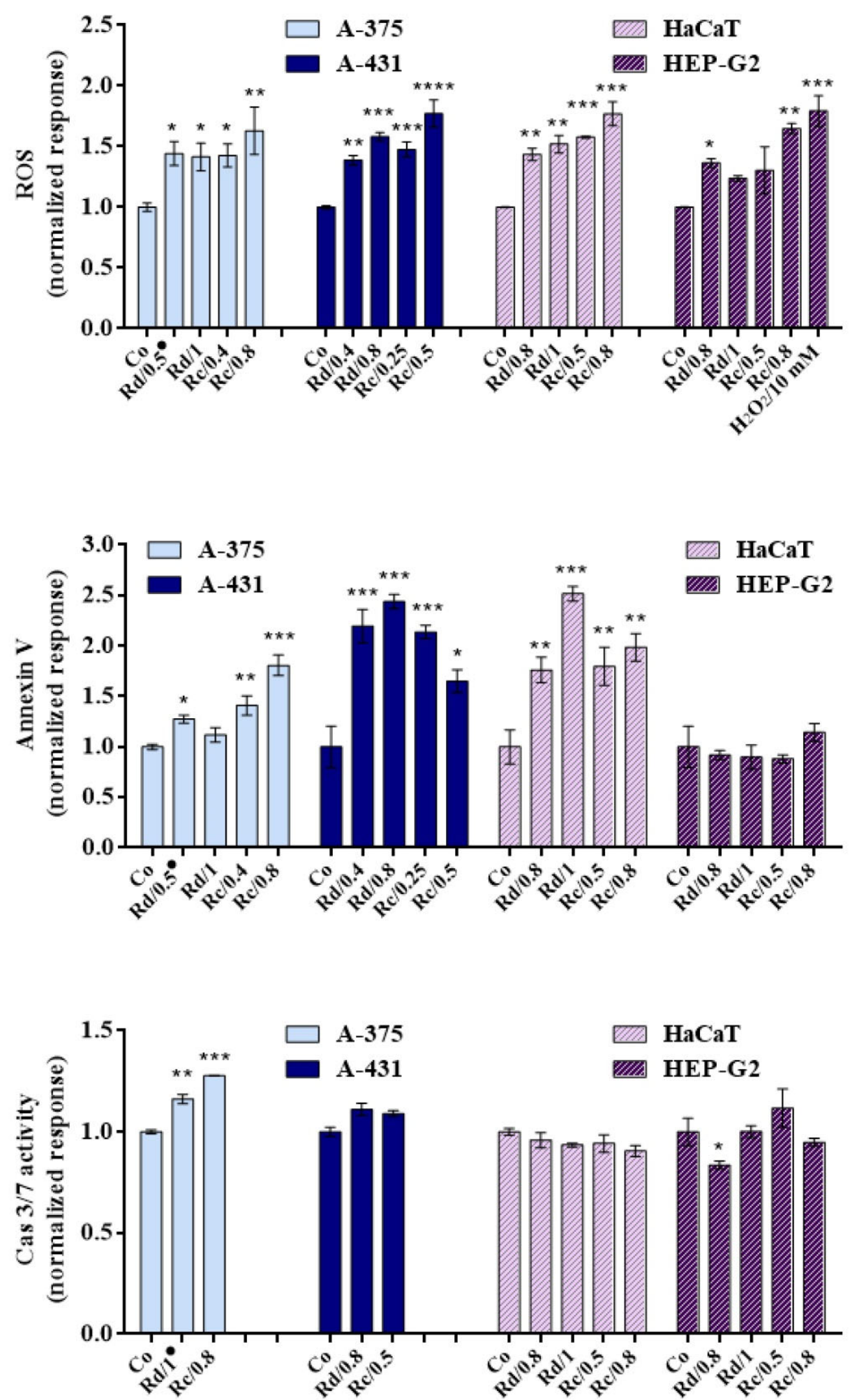

Figure 3. Generation of reactive oxygen species and induction of apoptosis after treatment of tumorigenic and non-tumorigenic cell lines with wastewater from two Rosa spp. for $48 \mathrm{~h}$. Legend: Co: control; Rd: R. damascena Mill.; Rc: R. centifolia L.; ${ }^{\bullet}$ : volumetric concentration (\%). Significant deviations from the untreated controls are denoted with asterisks $\left({ }^{*}\right.$ for $p<0.05,{ }^{* *}$ for $p<0.01,{ }^{* *}$ for $p<0.001,{ }^{* * * *}$ for $\left.p<0.0001\right)$. 


\subsection{Detection of Intracellular ROS Generation}

The results showed a strong induction of ROS in all cell lines. Treatment with the WWs was not selective, and induced an increase in the intracellular ROS in both the tumorigenic and non-tumorigenic cell lines.

\subsection{Effects of Rose Wastewaters on the Expression of the Enzyme CYP3A4}

After $24 \mathrm{~h}$ of exposure to the WWs, there was an increase in the concentration of CYP3A4 (induction) - to varying extents-in almost all of the treated samples (Figure 4, CYP 3A4). Notably, different doses of the WW from $R$. damascena showed a statistically significant response in both cell lines, but the response was inverse. The dose of $2 \mathrm{IC}_{50}$ induced CYP3A4 more than threefold in $\mathrm{HaCaT}$ cells, but the $\mathrm{IC}_{50}$ dose raised it only slightly. Meanwhile, in HEP-G2 cells, the dose of $\mathrm{IC}_{50}$ induced an almost threefold rise, while $2 \mathrm{IC}_{50}$ actually inhibited it slightly. The two doses of the WW from $R$. centifolia did not show such a dramatic difference. In HaCaT cells, the response differed little from the control $\left(2 \mathrm{IC}_{50}\right.$ reducing it by about $\left.1 / 3\right)$ while, in contrast, both doses induced the enzyme significantly in HEP-G2 cells.

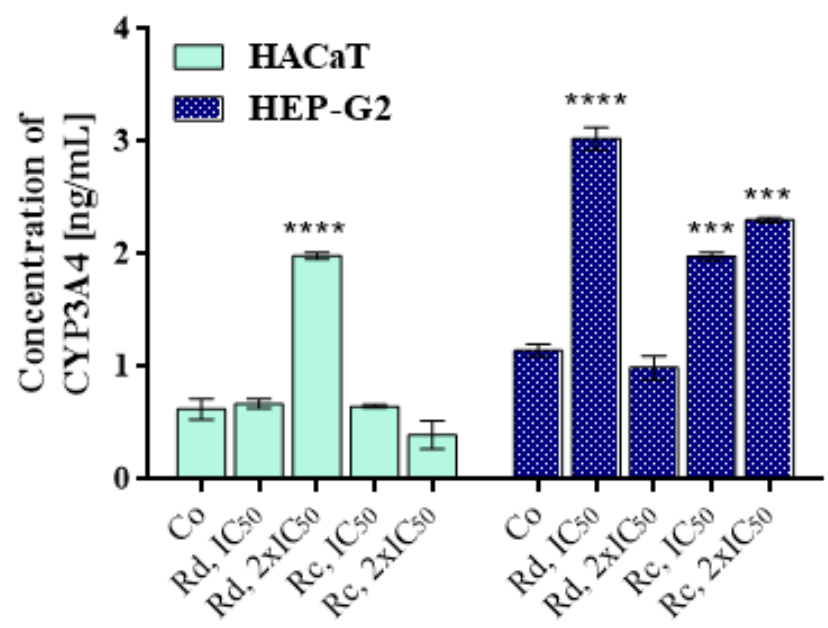

Figure 4. Effects of wastewaters obtained from Rosa damascena Mill. and Rosa centifolia L. on the concentration of the enzyme CYP3A4. Legend: Co: control; Rd: R. damascena Mill.; Rc: R. centifolia L.; $\mathrm{IC}_{50}$ : median inhibitory concentration for $72 \mathrm{~h}$ (see Table 3 ). Significant deviations from the untreated controls are denoted with asterisks $\left({ }^{* *}\right.$ for $p<0.001,{ }^{* * * *}$ for $\left.p<0.0001\right)$.

\subsection{Redox-Modulating Capacity of Rose Wastewaters}

The ability of WWs to reduce Fe(III) ions was determined via the FRAP method, and their activities were compared. Trolox was used as a reference substance, the maximum activity of which was assumed to be 1 , and the activities of the test samples were calculated against it. Analyzing the data shown in Table 5 and Figure 5, the four samples showed almost equivalent Fe(III)-reducing activity, but the most active was WW from $R$. damascena. The most pronounced metal-chelating action was shown by $R$. gallica (rich in gallic acid and ellagic acid) and $R$. alba (rich in ellagic acid) wastewaters. The strongest action as a reducer of $\mathrm{Cu}$ (II) was shown by $R$. centifolia (rich in tannins, kaempferol, and its derivatives) and $R$. alba (rich in ellagic acid) WWs. All of the WWs showed a well-defined concentration-effect relationship. 
Table 5. Median effective concentration of redox-modulating capacity of wastewaters from four different rose species, determined by $\mathrm{Cu}(\mathrm{I})$ - and $\mathrm{Fe}(\mathrm{II})$-chelating and $\mathrm{Fe}(\mathrm{III})$-reducing activity.

\begin{tabular}{|c|c|c|c|c|c|}
\hline \multicolumn{2}{|c|}{ Redox and Chelating Activity } & \multirow{2}{*}{$\begin{array}{c}\text { WW from } \\
\text { R. centifolia } \mathrm{L} \text {. }\end{array}$} & \multirow{2}{*}{$\begin{array}{l}\text { WW from } \\
\text { R. gallica L. }\end{array}$} & \multirow{2}{*}{$\begin{array}{l}\text { WW from } \\
\text { R. damascene Mill. }\end{array}$} & \multirow{2}{*}{$\begin{array}{l}\text { WW from } \\
\text { R. alba } \mathrm{L} \text {. }\end{array}$} \\
\hline Method & Model Parameters & & & & \\
\hline \multirow{3}{*}{ TEAC $_{\text {CUPRAC }}$} & HillSlope & 1.916 & 1.16 & 1.295 & 1.055 \\
\hline & $\mathrm{EC}_{50}$ & $0.409^{*}$ & $0.714 *$ & $0.699 *$ & $0.538 *$ \\
\hline & R (correlation coefficient) & 0.994 & 0.995 & 0.9998 & 0.998 \\
\hline \multirow{3}{*}{ FRAP } & HillSlope & 0.538 & 0.538 & 0.638 & 0.66 \\
\hline & $\mathrm{EC}_{50}$ & $0.0095 *$ & $0.009 *$ & $0.022 *$ & 0.019 * \\
\hline & $\mathrm{R}$ (correlation coefficient) & 0.998 & 0.995 & 0.999 & 0.998 \\
\hline \multirow{3}{*}{$\begin{array}{l}\text { Fe (II) chelation } \\
\text { activity }\end{array}$} & HillSlope & 0.072 & 0.715 & 0.560 & 0.715 \\
\hline & $\mathrm{EC}_{50}$ & $29.87^{*}$ & 18.99 * & $29.88^{*}$ & 18.99 * \\
\hline & R (correlation coefficient) & 0.920 & 0.968 & 0.928 & 0.968 \\
\hline
\end{tabular}

Legend: m: hillslope; EC: effective dose; $\mathrm{EC}_{50}$ : median effective concentration. R: coefficient of correlation; *: volumetric concentration (\% v/v).
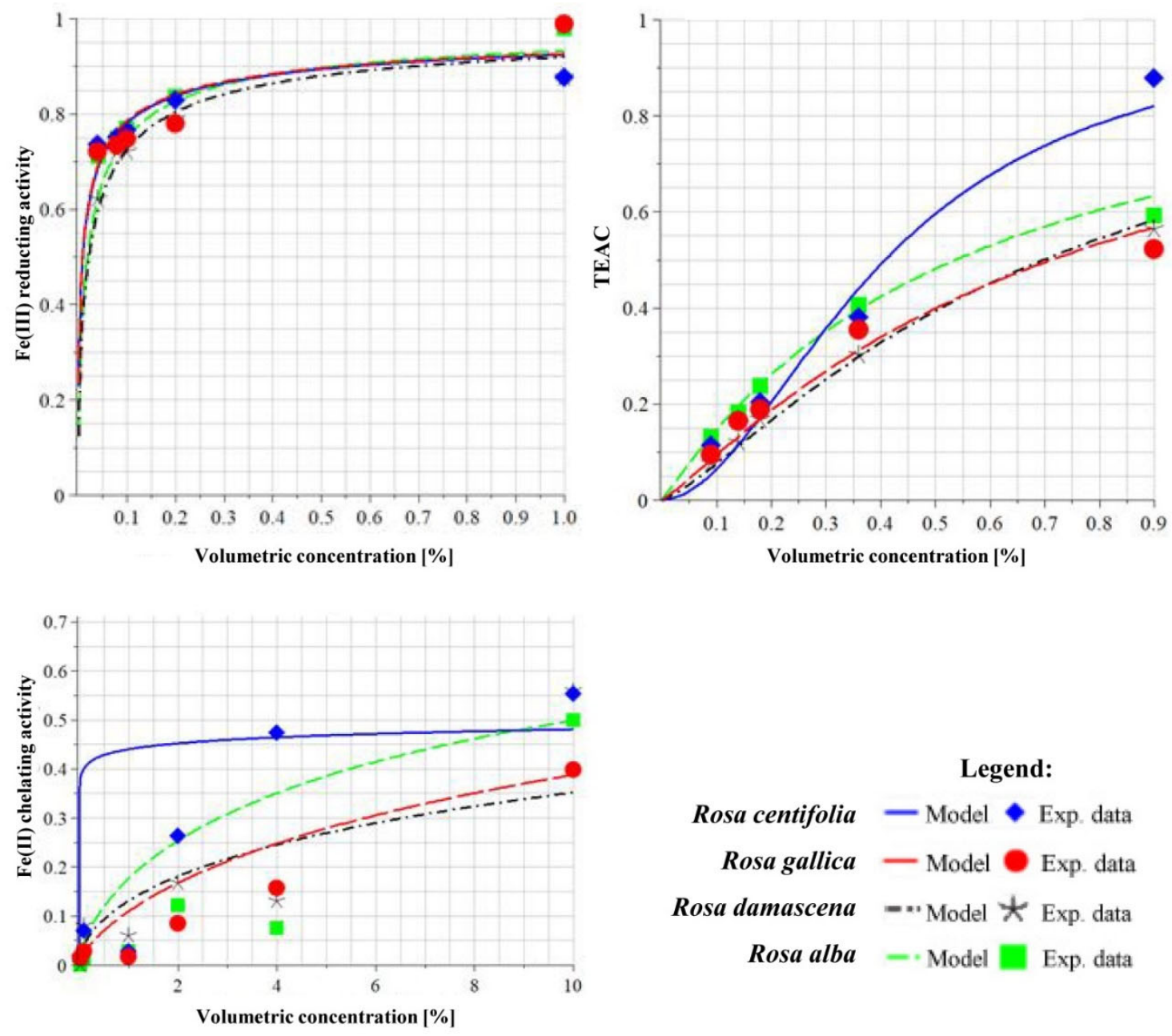

Legend:

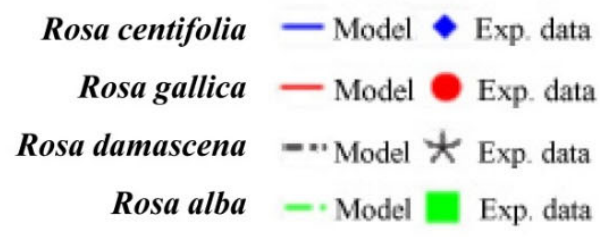

Figure 5. Quantitative evaluation through $\mathrm{IC}_{50}$ values of the redox-modulating capacity of wastewater samples, using a nonlinear median effect model.

\section{Discussion}

To the best of our knowledge, this is the first systematic study on the redox-modulating capacity and antitumor activity of rose wastewaters. It is primarily the essential oils and the organic solvent extracts from the roses or their petals that exert cytotoxic activity towards cancer cell lines, and this is valid also for $R$. damascena and its variety the Taif rose. As described in our recent review [105] regarding $\mathrm{IC}_{50}$, an isoprenylated aurone $\left(\mathrm{IC}_{50}\right.$ on acute 
myeloid leukemia NB4 cells $4.8 \mu \mathrm{M}$ and on neuroblastoma SHSY5Y cells $3.4 \mu \mathrm{M}$ ) from $R$. damascena and a crude methanol extract and its aqueous fraction from Taif rose ( $\mathrm{IC}_{50}$ of 9 and $8 \mu \mathrm{g} / \mathrm{mL}$ on hepatocellular carcinoma cells, respectively) [106,107] were the most active agents. Essential oils, and some organic solvent extracts and their fractions, of the aforementioned roses also have low-to-significant cytotoxic effects on normal cell lines.

There are diverse data on the water-soluble compounds from rose flowers:

- $\quad$ The water-soluble phase of the essential oils turned out to be a potent growth factor for gastric (MKN45) and colon (SW742) cancer cell lines, and even more so for normal fibroblasts [108,109];

- The water extract of petals was not cytotoxic to murine Ehrlich ascites carcinoma cells and peripheral blood leukocytes [110];

- Infusions from petals of R. damascena "Alexandria" and R. gallica "Francesa" drafted in R. canina had IC 50 values for breast (MCF-7), HEP-G2, and lung (NCI-H460) tumor cell lines of 377,315 , and $>400 \mu \mathrm{g} / \mathrm{mL}$, respectively [105,111].

There are many enzymatic sources of reactive oxygen species (ROS) in living organisms, including CYP enzymes, which contribute to the balance of cell oxidationreduction [112-114]. Disruption of normal redox balance leads to oxidative stress, and is involved in a number of disease processes, including carcinogenesis [115]. Normally, ROS perform a biological function, but overproduction of ROS causes cell damage through modifications of lipids, nucleic acids, and proteins, as well as triggering apoptosis. CYP enzymes are known to be a superfamily of monooxygenases, and many of them are responsible for the detoxification of xenobiotics. CYP enzymes are universal catalysts for a wide range of biochemical reactions, but are well known for their role in substrate oxidation [116]. Due to their oxidizing capacity, CYP enzymes play an important role in the metabolism of phase I drugs and xenobiotics, increasing the polarity of the substrates and promoting their excretion. CYP3A4 is the CYP isoform with the lowest substrate specificity (it metabolizes more xenobiotics than any other CYP isoform).

As we can see from the results presented in Figure 3, there was a strong induction of ROS and translocation of phosphatidylserine from the inner to the outer cell membrane in the malignant cell lines A-375 and A-431, in combination with caspase-3/7 induction. It is obvious that the tested WWs exert antineoplastic effects on both cell lines by inducing apoptosis. In the mammalian cells, there are two major apoptotic pathways: (1) the death receptor pathway, and (2) the mitochondrial pathway. Both pathways include the activation of caspase-3/7 as the main executor caspases. Caspases cause most of the visible changes that characterize apoptotic cell death, and can be thought of as the central executioners of the apoptotic pathways. The same pro-apoptotic concentrations of both of the tested WWs induce ROS generation in normal keratinocytes, as well as in the HEP-G2 cell line, which was used as a model for investigation of liver toxicity. Translocation of phosphatidylserine occurred only in the HaCaT keratinocytes, and there was no caspase-3/7 activation in these cell lines, in contrast to A-375 and A-431. The cytotoxicity assay showed higher $\mathrm{IC}_{50}$ values for the HaCaT and HEP-G2 cells; thus, the results from the caspase induction assay correlate directly with the results of the MTT assay. In addition, the lower induction of ROS by $R$. damascena WW in HEP-G2 cells at 48 h corresponds to the lower level of cytotoxicity in comparison to the WW of $R$. centifolia.

The lack of induction of apoptosis in HEP-G2 cells after a $48 \mathrm{~h}$ period of exposure to both WWs, as evidenced by the Annexin V test, is consistent with the cytotoxicity test. In the latter, as mentioned, HEP-G2 was invariably the most resistant cell line for the 48- and 24-hour periods of incubation. WW from R. centifolia increased the concentration of CYP3A4 only in HEP-G2 but not in HaCaT cells after incubation for $24 \mathrm{~h}$ (the MTT test confirmed that $R$. centifolia WW was the most cytotoxic to HaCaT cells for the $24 \mathrm{~h}$ exposure). The short-term induction of the CYP3A4 xenobiotic oxidase enzyme could cause or contribute to the resistance of the hepatic tumor cells to treatment. The effect of the WW from $R$. damascena was the induction of CYP3A4 in both cell lines, and this is 
supported by the results of the MTT test for $24 \mathrm{~h}$, where the effect of that WW towards $\mathrm{HaCaT}$ cells was almost as weak as towards HEP-G2 cells.

In principle, healthy cells and tissues are characterized by low levels of reactive oxygen species (ROS) and constant reference levels of reducing equivalents. Increasing ROS above a certain "critical" level provokes genome instability and the activation of proliferation, in which normal cells begin to transform into malignant cells. To maintain optimal cellular homeostasis, the regulation of cellular redox signaling is extremely important [117]. Upon initiation of cellular apoptosis, ROS are increased by disruption of the intracellular redox homeostasis and irreversible oxidative modifications of lipids, proteins, or DNA; this, in turn, may activate oxidative-stress-induced apoptotic signaling [118]. ROS have been shown to trigger the apoptosis of cancer cells via different mechanisms, including tumorrelated necrosis factor (TNF) $[119,120]$.

One of the effects of overproduction of ROS is ferroptosis; this is a type of irondependent oxidative cell death that can be caused by a variety of factors. Ferroptosis is different from apoptosis, but is also the result of dysfunction of antioxidant defense, leading to the loss of cellular redox homeostasis [121,122]. However, ferroptosis is also characterized by elevated levels of intracellular ROS [123].

An increase in ROS in the presence of iron ions has been shown to lead to ferroptosis. It appears that the accumulation of ROS and ferroptosis can be controlled by treatment with deferoxamine as an iron chelator [124].

The FRAP and CUPRAC methods are based on a single-electron transfer mechanism. The reducing power of FRAP is based on this mechanism, and cannot detect antioxidants that act by radical quenching ( $\mathrm{H}$ transfer). The method is based on the reduction of $\mathrm{Fe}(\mathrm{III})$ to $\mathrm{Fe}(\mathrm{II})$ [125]. The CUPRAC method is based on the reduction of $\mathrm{Cu}$ (II) to $\mathrm{Cu}$ (I) [125]. The reduction of iron and copper, as well as the formation of their complexes, is of critical importance, since when they are in a "free" form they can catalyze the production of highly toxic hydroxyl radicals [126].

The high metal reduction capacity in our study suggests that WWs of roses could be the first line of defense against copper toxicity, and could serve as copper chelators by sequestering the metal in a non-redox-active form. This mechanism of antioxidant activity is beneficial to living organisms due to the prevention of oxidative damage to the cellular membranes, and is essential for cell survival. According to our investigations, WWs might perform an essential detoxification function against ions of copper and iron. This function would be beneficial for maintaining metal homeostasis and protecting the function of cellular structures against the damaging effects of reactive oxygen species.

Antioxidants that have the ability to chelate and reduce iron (III) ions are potential candidates for controlling ferroptosis and its destructive effects on healthy cells.

In the context of our results, we hypothesize that the good iron-chelating properties of WWs from roses-especially those of the Damask rose-would serve as good lowcytotoxicity adjuvants in the treatment of oncogenic conditions associated with similar aspects of impaired redox homeostasis.

\section{Conclusions}

Recent years have witnessed a resurgence of global interest in herbal drugs. More and more people are turning to the use of herbal medicinal products in health care. It is high time that we revived the hidden wonders of the plant world, hidden in waste products that we have not appreciated for a long time-they must not be considered mere biological contaminants. In our work, we have studied a panel of bioactivities from wastewaters containing complex organic compounds available from the Bulgarian production of rose oil. We found that the WWs from four different Rosa spp. induce the executor caspase-3/7 in tumorigenic cell lines, but not in "normal" cells. The $\mathrm{IC}_{50}$ values for $72 \mathrm{~h}$ ranged between 33 and $83 \mu \mathrm{g} \mathrm{GAE} / \mathrm{mL}$ of polyphenols, which is a promising result for the future development of rose products for local treatment. The radical-modulating activity of the WWs can be used, depending on the concentrations applied, for chemoprevention, or as a 
part of combined chemotherapy after future pharmacological investigations. The chemical components of the WWs represent a promising source of new advanced generation agents with low cytotoxicity and pleiotropic pharmacological effects, such as antineoplastic and antioxidant activity, with a novel mode of action. In our opinion, this is only a promising beginning; hence, further studies are urgently needed for screening waste products and determining their bioactivities and properties in order to understand the complete phenomena of their healing potential.

Supplementary Materials: The following are available online at https:/ / www.mdpi.com/article / 10.3390/antiox10101615/s1: Table S1: Detected chemical constituents in wastewaters from Rosa damascena (RDAM), R. gallica (RGAL), R. centifolia (RCEN), and R. alba (RALB) by UHPLCHRMS/MS analysis. Table S2: Cytotoxicity $24 \mathrm{~h}$. Table S3: Cytotoxicity $48 \mathrm{~h}$.

Author Contributions: Conceptualization, M.M. and M.M.Z.; methodology, Y.I., A.D., P.N. and A.G.; software, A.K.; validation, M.M. and M.M.Z.; formal analysis, P.N. and A.K.; investigation, A.G., Y.I., P.N. and Z.K.-N.; resources, M.M., M.M.Z. and P.N.; data curation, A.D., M.M., M.M.Z., A.K., P.N. and A.G.; writing—original draft preparation, M.M., A.K., Y.I., M.M.Z., A.D., A.G. and P.N.; writing—review and editing, M.M.Z., M.M. and H.N.; visualization, M.M.Z., A.G., M.M., A.K., P.N. and Y.I.; supervision, M.M. and H.N.; project administration, M.M.; funding acquisition, M.M. and M.M.Z. All authors have read and agreed to the published version of the manuscript.

Funding: The authors are grateful to the Bulgarian National Science Fund for supporting this work by funding the project N KП-06-H36/17, granted to Milka Mileva.

Institutional Review Board Statement: Not applicable.

Informed Consent Statement: Not applicable.

Data Availability Statement: Data are contained within the article and Supplementary Materials.

Acknowledgments: The cell culturing, cytotoxicity, and apoptosis assays were performed using equipment donated to Maya M. Zaharieva by the Alexander von Humboldt Foundation in the frame of the program "Equipment Subsidies".

Conflicts of Interest: The authors declare no conflict of interest.

\section{References}

1. Baser, K.; Altintas, A.; Kurkcuoglu, M. Turkish rose: A review of the history, ethnobotany and modern uses of rose petals, rose oil, rose water and other rose products. HerbalGram 2012, 96, 40-53.

2. Labban, L.; Thallaj, N. The medicinal and pharmacological properties of Damascene Rose (Rosa damascena): A review. Int. J. Herb. Med. 2020, 8, 33-37.

3. Mahboubi, M. Rosa damascena as holy ancient herb with novel applications. J. Tradit. Complementary Med. 2016, 6, 10-16. [CrossRef] [PubMed]

4. Wedler, J.; Rusanov, K.; Atanassov, I.; Butterweck, V. A Polyphenol-Enriched Fraction of Rose Oil Distillation Wastewater Inhibits Cell Proliferation, Migration and TNF-alpha-Induced VEGF Secretion in Human Immortalized Keratinocytes. Planta Med. 2016, 82, 1000-1008. [CrossRef]

5. Kovatcheva, N.; Zheljazkov, V.D.; Astatkie, T. Productivity, oil content, composition, and bioactivity of oil-bearing rose accessions. HortScience 2011, 46, 710-714. [CrossRef]

6. Topalov, V. The Kazanluk Rose and Rose Production in Bulgaria; Khristo G. Danov: Plovdiv, Bulgaria, 1978.

7. Dobreva, A.; Velcheva, A.; Bardarov, V.; Bardarov, K. Chemical composition of different genotypes oil-bearing roses. Bulg. J. Agric. Sci. 2013, 19, 1213-1218.

8. Kovacheva, N.; Rusanov, K.; Atanassov, I. Industrial cultivation of oil bearing rose and rose oil production in Bulgaria during 21st century, directions and challenges. Biotechnol. Biotechnol. Equip. 2010, 24, 1793-1798. [CrossRef]

9. Slavov, A.; Vasileva, I.; Stefanov, L.; Stoyanova, A. Valorization of wastes from the rose oil industry. Rev. Environ. Sci. Bio/Technol. 2017, 16, 309-325. [CrossRef]

10. Sabahi, Z.; Farmani, F.; Mousavinoor, E.; Moein, M. Valorization of Waste Water of Rosa damascena Oil Distillation Process by Ion Exchange Chromatography. Sci. World J. 2020, 2020, 5409493. [CrossRef] [PubMed]

11. Rothfuss, A.; Honma, M.; Czich, A.; Aardema, M.J.; Burlinson, B.; Galloway, S.; Hamada, S.; Kirkland, D.; Heflich, R.H.; Howe, J.; et al. Improvement of in vivo genotoxicity assessment: Combination of acute tests and integration into standard toxicity testing. Mutat. Res. 2011, 723, 108-120. [CrossRef] [PubMed] 
12. Naikwade, N.S.; Mule, S.N.; Adnaik, R.S.; Magdum, C.S. Memory-enhancing activity of Rose alba in mice. Int. J. Green Pharm. 2009, 3, 239-242. [CrossRef]

13. Gottlieb, O.R.; Borin, M.R. Medicinal products: Regulation of biosynthesis in space and time. Mem. Inst. Oswaldo Cruz. 2000, 95, 115-120. [CrossRef]

14. Mollov, P.; Mihalev, K.; Shikov, V.; Yoncheva, N.; Karagyozov, V. Colour stability improvement of strawberry beverage by fortification with polyphenolic copigments naturally occurring in rose petals. Innov. Food Sci. Emerg. Technol. 2007, 8, 318-321. [CrossRef]

15. Prasain, J.K.; Barnes, S. Uptake and Metabolism of Dietary Proanthocyanidins; Academic Press: Cambridge, MA, USA, 2014.

16. Santos-Sánchez, N.F.; Salas-Coronado, R.; Villanueva-Cañongo, C.; Hernández-Carlos, B. Antioxidant Compounds and Their Antioxidant Mechanism; IntechOpen: London, UK, 2019.

17. Di Domenico, F.; Barone, E.; Perluigi, M.; Butterfield, D.A. Strategy to reduce free radical species in Alzheimer's disease: An update of selected antioxidants. Expert Rev. Neurother. 2015, 15, 19-40. [CrossRef]

18. Simons, B.D.; Clevers, H. Strategies for homeostatic stem cell self-renewal in adult tissues. Cell 2011, 145, 851-862. [CrossRef] [PubMed]

19. Wang, K.; Zhang, T.; Dong, Q.; Nice, E.C.; Huang, C.; Wei, Y. Redox homeostasis: The linchpin in stem cell self-renewal and differentiation. Cell Death Dis. 2013, 4, e537. [CrossRef]

20. Abdel-Hameed, E.S.S.; Bazaid, S.A.; Sabra, A.N.A. Total phenolic, in vitro antioxidant activity and safety assessment (acute, sub-chronic and chronic toxicity) of industrial taif rose water by-product in mice. Der. Pharm. Lett. 2015, 7, 251-259.

21. Rusanov, K.; Garo, E.; Rusanova, M.; Fertig, O.; Hamburger, M.; Atanassov, I.; Butterweck, V. Recovery of polyphenols from rose oil distillation wastewater using adsorption resins-A pilot study. Planta Med. 2014, 80, 1657-1664. [CrossRef]

22. Rusanov, K.; Kovacheva, N.; Vosman, B.; Zhang, L.; Rajapakse, S.; Atanassov, A.; Atanassov, I. Microsatellite analysis of Rosa damascena Mill. accessions reveals genetic similarity between genotypes used for rose oil production and old Damask rose varieties. Theor. Appl. Genet 2005, 111, 804-809. [CrossRef]

23. Tabaei-Aghdaei, S.R.; Babaei, A.; Khosh-Khui, M.; Jaimand, K.; Rezaee, M.B.; Assareh, M.H.; Naghavi, M.R. Morphological and oil content variations amongst Damask rose (Rosa damascena Mill.) landraces from different regions of Iran. Sci. Hortic. 2007, 113, 44-48. [CrossRef]

24. Papasian, C.; Hentges, S.; Banerjee, S.; Haque, I.; Banerjee, S.K. Emblica officinalis extract induces autophagy and inhibits human ovarian cancer cell proliferation, angiogenesis, growth of mouse xenograft tumors. PLoS ONE 2013, 8, e72748. [CrossRef]

25. Sourani, Z.; Pourgheysari, B.; Beshkar, P.; Shirzad, H.; Shirzad, M. Gallic acid inhibits proliferation and induces apoptosis in lymphoblastic leukemia cell line (C121). Iran. J. Med. Sci. 2016, 41, 525.

26. He, Z.; Li, B.; Rankin, G.O.; Rojanasakul, Y.; Chen, Y.C. Selecting bioactive phenolic compounds as potential agents to inhibit proliferation and VEGF expression in human ovarian cancer cells. Oncol. Lett. 2015, 9, 1444-1450. [CrossRef] [PubMed]

27. Han, Y.H.; Park, W.H. Growth inhibition in antimycin A treated-lung cancer Calu- 6 cells via inducing a G1 phase arrest and apoptosis. Lung Cancer 2009, 65, 150-160. [CrossRef] [PubMed]

28. Park, W.H. Gallic acid induces HeLa cell death via increasing GSH depletion rather than ROS levels. Oncol. Rep. 2017, 37, 1277-1283. [CrossRef] [PubMed]

29. You, B.R.; Kim, S.Z.; Kim, S.H.; Park, W.H. Gallic acid-induced lung cancer cell death is accompanied by ROS increase and glutathione depletion. Mol. Cell Biochem. 2011, 357, 295-303. [CrossRef] [PubMed]

30. You, B.R.; Moon, H.J.; Han, Y.H.; Park, W.H. Gallic acid inhibits the growth of HeLa cervical cancer cells via apoptosis and/or necrosis. Food Chem. Toxicol. 2010, 48, 1334-1340. [CrossRef]

31. You, B.R.; Park, W.H. Gallic acid-induced lung cancer cell death is related to glutathione depletion as well as reactive oxygen species increase. Toxicol. Vitro 2010, 24, 1356-1362. [CrossRef]

32. Zhang, T.; Ma, L.; Wu, P.; Li, W.; Li, T.; Gu, R.; Dan, X.; Li, Z.; Fan, X.; Xiao, Z. Gallic acid has anticancer activity and enhances the anticancer effects of cisplatin in non-small cell lung cancer A549 cells via the JAK/STAT3 signaling pathway. Oncol. Rep. 2019, 41, 1779-1788. [CrossRef]

33. Zhao, B.; Hu, M. Gallic acid reduces cell viability, proliferation, invasion and angiogenesis in human cervical cancer cells. Oncol. Lett. 2013, 6, 1749-1755. [CrossRef]

34. Khorsandi, K.; Kianmehr, Z.; Hosseinzadeh, R. Anti-cancer effect of gallic acid in presence of low level laser irradiation: ROS production and induction of apoptosis and ferroptosis. Cancer Cell Int. 2020, 20, 1-14. [CrossRef]

35. Yoshino, M.; Haneda, M.; Naruse, M.; Htay, H.H.; Iwata, S.; Tsubouchi, R.; Murakami, K. Prooxidant action of gallic acid compounds: Copper-dependent strand breaks and the formation of 8-hydroxy-2'-deoxyguanosine in DNA. Toxicol. Vitro 2002, 16, 705-709. [CrossRef]

36. Tanaka, T.; Kojima, T.; Kawamori, T.; Yoshimi, N.; Mori, H. Chemoprevention of diethylnitrosamine-induced hepatocarcinogenesis by a simple phenolic acid protocatechuic acid in rats. Cancer Res. 1993, 53, 2775-2779. [PubMed]

37. Kakkar, S.; Bais, S. A review on protocatechuic Acid and its pharmacological potential. ISRN Pharmacol. 2014, $2014,952943$. [CrossRef]

38. Li, X.; Wang, X.; Chen, D.; Chen, S. Antioxidant activity and mechanism of protocatechuic acid in vitro. Funct. Foods Health Dis. 2011, 1, 232-244. [CrossRef] 
39. Ding, Y.; Ren, D.; Xu, H.; Liu, W.; Liu, T.; Li, L.; Li, J.; Li, Y.; Wen, A. Antioxidant and pro-angiogenic effects of corilagin in rat cerebral ischemia via Nrf2 activation. Oncotarget 2017, 8, 114816-114828. [CrossRef] [PubMed]

40. Gupta, A.; Singh, A.K.; Kumar, R.; Ganguly, R.; Rana, H.K.; Pandey, P.K.; Sethi, G.; Bishayee, A.; Pandey, A.K. Corilagin in Cancer: A Critical Evaluation of Anticancer Activities and Molecular Mechanisms. Molecules 2019, 24, 3399. [CrossRef] [PubMed]

41. Li, X.; Deng, Y.; Zheng, Z.; Huang, W.; Chen, L.; Tong, Q.; Ming, Y. Corilagin, a promising medicinal herbal agent. Biomed. Pharmacother. 2018, 99, 43-50. [CrossRef] [PubMed]

42. Cordeiro, Y.D.G.; Rochetti, A.L.; Souza, V.C.; Silva, E.R.D.; Scatolini, A.M.; Genovese, M.I.; Yasui, G.S.; Fukumasu, H. Antineoplastic effect of procyanidin-rich extract of Lafoensia Pacari in lung carcinoma cells. Braz. Arch. Biol. Technol. $2019,62$. [CrossRef]

43. Wu, X.; Yu, H.; Zhou, H.; Li, Z.; Huang, H.; Xiao, F.; Xu, S.; Yang, Y. Proanthocyanidin B2 inhibits proliferation and induces apoptosis of osteosarcoma cells by suppressing the PI3K/AKT pathway. J. Cell Mol. Med. 2020, 24, 11960-11971. [CrossRef]

44. Barbe, A.; Rame, C.; Mellouk, N.; Estienne, A.; Bongrani, A.; Brossaud, A.; Riva, A.; Guerif, F.; Froment, P.; Dupont, J. Effects of Grape Seed Extract and Proanthocyanidin B2 on In Vitro Proliferation, Viability, Steroidogenesis, Oxidative Stress, and Cell Signaling in Human Granulosa Cells. Int. J. Mol. Sci. 2019, 20, 4215. [CrossRef]

45. Bae, J.; Kim, N.; Shin, Y.; Kim, S.Y.; Kim, Y.J. Activity of catechins and their applications. Biomed. Dermatol. 2020, 4, 1-10. [CrossRef]

46. Lukitasari, M.; Nugroho, D.A.; Widodo, N. Chlorogenic Acid: The Conceivable Chemosensitizer Leading to Cancer Growth Suppression. J. Evid. Based Integr. Med. 2018, 23, 2515690X18789628. [CrossRef] [PubMed]

47. Sapio, L.; Salzillo, A.; Illiano, M.; Ragone, A.; Spina, A.; Chiosi, E.; Pacifico, S.; Catauro, M.; Naviglio, S. Chlorogenic acid activates ERK1/2 and inhibits proliferation of osteosarcoma cells. J. Cell Physiol. 2020, 235, 3741-3752. [CrossRef]

48. Xu, J.G.; Hu, Q.P.; Liu, Y. Antioxidant and DNA-protective activities of chlorogenic acid isomers. J. Agric. Food Chem. 2012, 60, 11625-11630. [CrossRef] [PubMed]

49. Takanashi, K.; Suda, M.; Matsumoto, K.; Ishihara, C.; Toda, K.; Kawaguci, K.; Senga, S.; Kobayashi, N.; Ichikawa, M.; Katoh, M.; et al. Epicatechin oligomers longer than trimers have anti-cancer activities, but not the catechin counterparts. Sci. Rep. 2017, 7, 1-13. [CrossRef] [PubMed]

50. Tvrda, E.; Straka, P.; Galbavy, D.; Ivanic, P. Epicatechin Provides Antioxidant Protection to Bovine Spermatozoa Subjected to Induced Oxidative Stress. Molecules 2019, 24, 3226. [CrossRef] [PubMed]

51. Baradaran Rahimi, V.; Ghadiri, M.; Ramezani, M.; Askari, V.R. Antiinflammatory and anti-cancer activities of pomegranate and its constituent, ellagic acid: Evidence from cellular, animal, and clinical studies. Phytother. Res. 2020, 34, 685-720. [CrossRef] [PubMed]

52. Bell, C.; Hawthorne, S. Ellagic acid, pomegranate and prostate cancer-A mini review. J Pharm. Pharmacol. 2008, 60, 139-144. [CrossRef]

53. Cetin, A.; Biltekin, B.; Degirmencioglu, S. Ellagic Acid Enhances the Antitumor Efficacy of Bevacizumab in an In Vitro Glioblastoma Model. World Neurosurg. 2019, 132, e59-e65. [CrossRef]

54. Cheshomi, H.; Bahrami, A.R.; Matin, M.M. Ellagic acid and human cancers: A systems pharmacology and docking study to identify principal hub genes and main mechanisms of action. Mol. Divers. 2021, 25, 333-349. [CrossRef]

55. Han, D.H.; Lee, M.J.; Kim, J.H. Antioxidant and apoptosis-inducing activities of ellagic acid. Anticancer Res 2006, 26, 3601-3606.

56. Muthukumaran, S.; Tranchant, C.; Shi, J.; Ye, X.; Xue, S.J. Ellagic acid in strawberry (Fragaria spp.): Biological, technological, stability, and human health aspects. Food Qual. Saf. 2017, 1, 227-252. [CrossRef]

57. Okumura, T. The Potential as New Treatment Agent of Urolithin-A Metabolized from Ellagic Acid by Gut Microbiota in Cancer. Juntendo Med. J. 2021, 67, 131-139. [CrossRef]

58. Priyadarsini, K.I.; Khopde, S.M.; Kumar, S.S.; Mohan, H. Free radical studies of ellagic acid, a natural phenolic antioxidant. J. Agric. Food Chem. 2002, 50, 2200-2206. [CrossRef] [PubMed]

59. Wang, Y.; Ren, F.; Li, B.; Song, Z.; Chen, P.; Ouyang, L. Ellagic acid exerts antitumor effects via the PI3K signaling pathway in endometrial cancer. J. Cancer 2019, 10, 3303-3314. [CrossRef] [PubMed]

60. Xu, H.; Chen, F.; Liu, T.; Xu, J.; Li, J.; Jiang, L.; Wang, X.; Sheng, J. Ellagic acid blocks RANKL-RANK interaction and suppresses RANKL-induced osteoclastogenesis by inhibiting RANK signaling pathways. Chem.-Biol. Interact. 2020, 331, 109235. [CrossRef] [PubMed]

61. Buonerba, C.; De Placido, P.; Bruzzese, D.; Pagliuca, M.; Ungaro, P.; Bosso, D.; Ribera, D.; Iaccarino, S.; Scafuri, L.; Liotti, A.; et al. Isoquercetin as an adjunct therapy in patients with kidney cancer receiving first-line sunitinib (QUASAR): Results of a phase I trial. Front. Pharmacol. 2018, 9, 189. [CrossRef]

62. Caparica, R.; Julio, A.; Araujo, M.E.M.; Baby, A.R.; Fonte, P.; Costa, J.G.; Santos de Almeida, T. Anticancer Activity of Rutin and Its Combination with Ionic Liquids on Renal Cells. Biomolecules 2020, 10, 233. [CrossRef] [PubMed]

63. Imani, A.; Maleki, N.; Bohlouli, S.; Kouhsoltani, M.; Sharifi, S.; Maleki Dizaj, S. Molecular mechanisms of anticancer effect of rutin. Phytother. Res. 2021, 35, 2500-2513. [CrossRef]

64. Nouri, Z.; Fakhri, S.; Nouri, K.; Wallace, C.E.; Farzaei, M.H.; Bishayee, A. Targeting multiple signaling pathways in cancer: The rutin therapeutic approach. Cancers 2020, 12, 2276. [CrossRef]

65. Saleh, A.; ElFayoumi, H.M.; Youns, M.; Barakat, W. Rutin and orlistat produce antitumor effects via antioxidant and apoptotic actions. Naunyn Schmiedebergs Arch. Pharmacol. 2019, 392, 165-175. [CrossRef] 
66. Shahid, A.; Ali, R.; Ali, N.; Hasan, S.K.; Rashid, S.; Majed, F.; Sultana, S. Attenuation of genotoxicity, oxidative stress, apoptosis and inflammation by rutin in benzo(a)pyrene exposed lungs of mice: Plausible role of NF-kappaB, TNF-alpha and Bcl-2. $J$ Complement Integr. Med. 2016, 13, 17-29. [CrossRef]

67. Tapas, A.R.; Sakarkar, D.M.; Kakde, R.B. Flavonoids as nutraceuticals: A review. Tropical J. Pharm. Res. 2008, 7, 1089-1099. [CrossRef]

68. Khan, F.; Pandey, P.; Upadhyay, T.K.; Jafri, A.; Jha, N.K.; Mishra, R.; Singh, V. Anti-Cancerous Effect of Rutin Against HPV-C33A Cervical Cancer Cells via G0/G1 Cell Cycle Arrest and Apoptotic Induction. Endocr. Metab. Immune Disord. Drug. Targets 2020, 20, 409-418. [CrossRef] [PubMed]

69. Baliga, M.S. Anticancer, chemopreventive and radioprotective potential of black plum (Eugenia jambolana lam.). Asian Pac. J. Cancer Prev. 2011, 12, 3-15. [PubMed]

70. Garg, S.K.; Shukla, A.; Choudhury, S. Polyphenols and Flavonoids; Springer: Berlin/Heidelberg, Germany, 2019.

71. Ran, J.; Wang, Y.; Zhang, W.; Ma, M.; Zhang, H. Research on the bioactivity of isoquercetin extracted from marestail on bladder cancer EJ cell and the mechanism of its occurrence. Artif. Cells Nanomed. Biotechnol. 2016, 44, 859-864. [CrossRef] [PubMed]

72. Singh, Y.; Bhatnagar, P.; Kumar, S. A review on bio-active compounds and medicinal strength of Jamun (Syzygium cumini Skeels. IJCS 2019, 7, 3112-3117.

73. Wang, R.; Ding, Y.; Liu, R.; Xiang, L.; Du, L. Pomegranate: Constituents, bioactivities and pharmacokinetics. Fruit Veg. Cereal Sci. Biotechnol. 2010, 4, 77-87.

74. Kumar, M.; Tomar, M.; Amarowicz, R.; Saurabh, V.; Nair, M.S.; Maheshwari, C.; Sasi, M.; Prajapati, U.; Hasan, M.; Singh, S.; et al. Guava (Psidium guajava L.) Leaves: Nutritional Composition, Phytochemical Profile, and Health-Promoting Bioactivities. Foods 2021, 10, 752. [CrossRef]

75. Lee, J.S.; Lee, A.Y.; Quilantang, N.G.; Geraldino, P.J.L.; Cho, E.J.; Lee, S. Anti-oxidant activity of avicularin and isovitexin from Lespedeza cuneata. J. Appl. Biol. Chem. 2019, 62, 143-147. [CrossRef]

76. Wang, Z.; Li, F.; Quan, Y.; Shen, J. Avicularin ameliorates human hepatocellular carcinoma via the regulation of NF- $\mathrm{kB} / \mathrm{COX}-$ 2/PPAR- $\gamma$ activities. Mol. Med. Rep. 2019, 19, 5417-5423. [CrossRef]

77. Hofmann, J.; Fiebig, H.H.; Winterhalter, B.R.; Berger, D.P.; Grunicke, H. Enhancement of the antiproliferative activity of cisdiamminedichloroplatinum(II) by quercetin. Int. J. Cancer 1990, 45, 536-539. [CrossRef] [PubMed]

78. Kubina, R.; Iriti, M.; Kabala-Dzik, A. Anticancer Potential of Selected Flavonols: Fisetin, Kaempferol, and Quercetin on Head and Neck Cancers. Nutrients 2021, 13, 845. [CrossRef] [PubMed]

79. Li, N.; Sun, C.; Zhou, B.; Xing, H.; Ma, D.; Chen, G.; Weng, D. Low concentration of quercetin antagonizes the cytotoxic effects of anti-neoplastic drugs in ovarian cancer. PLoS ONE 2014, 9, e100314. [CrossRef] [PubMed]

80. Li, W.; Shen, F.; Weber, G. Ribavirin and quercetin synergistically downregulate signal transduction and are cytotoxic in human ovarian carcinoma cells. Oncol. Res. 1999, 11, 243-247.

81. Wang, G.; Song, L.; Wang, H.; Xing, N. Quercetin synergizes with 2-methoxyestradiol inhibiting cell growth and inducing apoptosis in human prostate cancer cells. Oncol. Rep. 2013, 30, 357-363. [CrossRef]

82. Ozgen, S.; Kilinc, O.K.; Selamoğlu, Z. Antioxidant activity of quercetin: A mechanistic review. Turk. J. Agric.-Food Sci. Technol. 2016, 4, 1134-1138. [CrossRef]

83. Vasquez-Espinal, A.; Yanez, O.; Osorio, E.; Areche, C.; Garcia-Beltran, O.; Ruiz, L.M.; Cassels, B.K.; Tiznado, W. Theoretical Study of the Antioxidant Activity of Quercetin Oxidation Products. Front. Chem. 2019, 7, 818. [CrossRef]

84. Zheng, Y.Z.; Deng, G.; Liang, Q.; Chen, D.F.; Guo, R.; Lai, R.C. Antioxidant Activity of Quercetin and Its Glucosides from Propolis: A Theoretical Study. Sci. Rep. 2017, 7, 7543. [CrossRef]

85. Daniela, A.; Pichichero, E.; Canuti, L.; Cicconi, R.; Karou, D.; D’Arcangelo, G.; Canini, A. Identification of phenolic compounds from medicinal and melliferous plants and their cytotoxic activity in cancer cells. Caryologia 2007, 60, 90-95. [CrossRef]

86. Kim, S.H.; Choi, K.C. Anti-cancer Effect and Underlying Mechanism(s) of Kaempferol, a Phytoestrogen, on the Regulation of Apoptosis in Diverse Cancer Cell Models. Toxicol. Res. 2013, 29, 229-234. [CrossRef]

87. Kulanthaivel, L.; Srinivasan, P.; Shanmugam, V.; Periyasamy, B.M. Therapeutic efficacy of kaempferol against AFB1 induced experimental hepatocarcinogenesis with reference to lipid peroxidation, antioxidants and biotransformation enzymes. Biomed. Prev. Nutr. 2012, 2, 252-259. [CrossRef]

88. Dar, R.A.; Brahman, P.K.; Khurana, N.; Wagay, J.A.; Lone, Z.A.; Ganaie, M.A.; Pitre, K.S. Evaluation of antioxidant activity of crocin, podophyllotoxin and kaempferol by chemical, biochemical and electrochemical assays. Arab. J. Chem. 2017, 10, S1119-S1128. [CrossRef]

89. COE. Tannins in herbal drugs. In European Pharmacopoeia, 8th ed.; Council of Europe (COE)—European Directorate for the Quality of Medicines (EDQM): Strasbourg, France, 2013; pp. 275-276.

90. COE. Safflower Flower (Carthami flos). In European Pharmacopoeia, 8th ed.; Council of Europe (COE)-European Directorate for the Quality of Medicines (EDQM): Strasbourg, France, 2013; pp. 1371-1372.

91. Zheng, W.; Wang, S.Y. Antioxidant activity and phenolic compounds in selected herbs. J. Agric. Food Chem. 2001, 49, 5165-5170. [CrossRef]

92. Hep G2 [HEPG2]. Available online: https:/ /www.atcc.org/products/hb-8065 (accessed on 20 September 2021). 
93. Slany, A.; Haudek, V.J.; Zwickl, H.; Gundacker, N.C.; Grusch, M.; Weiss, T.S.; Seir, K.; Rodgarkia-Dara, C.; Hellerbrand, C.; Gerner, C. Cell characterization by proteome profiling applied to primary hepatocytes and hepatocyte cell lines Hep-G2 and Hep-3B. J. Proteome Res. 2010, 9, 6-21. [CrossRef]

94. Qiu, G.H.; Xie, X.; Xu, F.; Shi, X.; Wang, Y.; Deng, L. Distinctive pharmacological differences between liver cancer cell lines HepG2 and Hep3B. Cytotechnology 2015, 67, 1-12. [CrossRef] [PubMed]

95. Moscato, S.; Ronca, F.; Campani, D.; Danti, S. Poly (vinyl alcohol)/gelatin hydrogels cultured with HepG2 cells as a 3D model of hepatocellular carcinoma: A morphological study. J. Funct. Biomat. 2015, 6, 16-32. [CrossRef] [PubMed]

96. Donato, M.T.; Tolosa, L.; Gomez-Lechon, M.J. Culture and Functional Characterization of Human Hepatoma HepG2 Cells. Methods Mol. Biol. 2015, 1250, 77-93. [CrossRef] [PubMed]

97. Ilieva, Y.; Dimitrova, L.; Zaharieva, M.M.; Kaleva, M.; Alov, P.; Tsakovska, I.; Pencheva, T.; Pencheva, I.; Najdenski, H.; Pajeva, I. Cytotoxicity and Microbicidal Activity of Commonly Used Organic Solvents: A Comparative Study and Application to a Standardized Extract from Vaccinium Macrocarpon. Toxics 2021, 9, 92. [CrossRef]

98. Zaharieva, M.M.; Trochopoulos, A.; Dimitrova, L.; Berger, M.R.; Najdenski, H.; Konstantinov, S.; Kroumov, A.D. New Insights in Routine Procedure for Mathematical Evaluation of in vitro Cytotoxicity Data from Cancer Cell Lines. Int. J. Bioautomation 2018, 22, 87-106. [CrossRef]

99. Chou, T.C.; Talalay, P. Quantitative analysis of dose-effect relationships: The combined effects of multiple drugs or enzyme inhibitors. Adv. Enzym. Regul. 1984, 22, 27-55. [CrossRef]

100. Benzie, I.F.; Strain, J.J. The ferric reducing ability of plasma (FRAP) as a measure of "antioxidant power": The FRAP assay. Anal. Biochem. 1996, 239, 70-76. [CrossRef] [PubMed]

101. Apak, R.; Guclu, K.; Ozyurek, M.; Karademir, S.E. Novel total antioxidant capacity index for dietary polyphenols and vitamins C and E, using their cupric ion reducing capability in the presence of neocuproine: CUPRAC method. J. Agric. Food Chem. 2004, 52, 7970-7981. [CrossRef] [PubMed]

102. Venditti, E.; Bacchetti, T.; Tiano, L.; Carloni, P.; Greci, L.; Damiani, E. Hot vs. cold water steeping of different teas: Do they affect antioxidant activity? Food Chem. 2010, 119, 1597-1604. [CrossRef]

103. Boik, J. Natural Compounds in Cancer Therapy; Medical Press: Oregon, Princeton, MN, USA, 2001.

104. Hengartner, M.O. The biochemistry of apoptosis. Nature 2000, 407, 770-776. [CrossRef] [PubMed]

105. Mileva, M.; Ilieva, Y.; Jovtchev, G.; Gateva, S.; Zaharieva, M.M.; Georgieva, A.; Dimitrova, L.; Dobreva, A.; Angelova, T.; Vilhelmova-Ilieva, N.; et al. Rose Flowers-A Delicate Perfume or a Natural Healer? Biomolecules 2021, 11, 127. [CrossRef]

106. Wang, H.; Yang, J.-X.; Lou, J.; Li, L.; Liu, G.-Y.; Hu, Q.-F.; Ye, Y.-Q.; Gao, X.-M. A New Isoprenylated Aurone from the Flowers of Rosa damascene and Its Cytotoxicities. Asian J. Chem. 2014, 26, 7122-7124. [CrossRef]

107. Abdel-Hameed, E.S.S.; Bazaid, S.A.; Salman, M.S. Characterization of the phytochemical constitu-ents of taif rose and its antioxidant and anticancer activities. BioMed Res. Int. 2013, 2013, 345465. [CrossRef]

108. Khatib, H.; Rezaei-Tavirani, M.; Keshel, S.H.; Azodi, M.Z.; Omidi, R.; Biglarian, M.; Sobhi, S. Flow cytometry analysis of Rosa Damascena effects on gastric cancer cell line (MKN45). Iran. J. Cancer Prev. 2013, 6, 30-36.

109. Rezaie-Tavirani, M.; Fayazfar, S.; Heydari-Keshel, S.; Rezaee, M.B.; Zamanian-Azodi, M.; Rezaei-Tavirani, M.; Khodarahmi, R. Effect of essential oil of Rosa Damascena on human colon cancer cell line SW742. Gastroenterol. Hepatol. Bed Bench 2013, 6, 25-31.

110. Antonyan, A.; Sharoyan, S.; Harutyunyan, H.; Movsisyan, N.; Sargisova, Y.; Stepanyan, H.; Mlardanyan, S. Cytotoxicity of Some Edible Plants toward Ehrlich Ascites. Res. J. Med. Plant 2014, 8, 20-31. [CrossRef]

111. Pires, T.C.; Dias, M.I.; Barros, L.; Calhelha, R.C.; Alves, M.J.; Oliveira, M.B.P.; Ferreira, I.C. Edible flowers as sources of phenolic compounds with bioactive potential. Food Res. Int. 2018, 105, 580-588. [CrossRef] [PubMed]

112. Holmström, K.M.; Finkel, T. Cellular mechanisms and physiological consequences of redox-dependent signalling. Nat. Rev. Mol. Cell Biol. 2014, 15, 411-421. [CrossRef] [PubMed]

113. Jones, D.P.; Sies, H. The Redox Code. Antioxid. Redox. Signal. 2015, 23, 734-746. [CrossRef]

114. Veith, A.; Moorthy, B. Role of cytochrome P450s in the generation and metabolism of reactive oxygen species. Curr. Opin. Toxicol. 2018, 7, 44-51. [CrossRef]

115. Sies, H.; Berndt, C.; Jones, D.P. Oxidative stress. Ann. Rev. Biochem. 2017, 86, 715-748. [CrossRef]

116. Guengerich, F.P. Common and uncommon cytochrome P450 reactions related to metabolism and chemical toxicity. Chem. Res. Toxicol. 2001, 14, 611-650. [CrossRef]

117. Ivanova, D.; Zhelev, Z.; Aoki, I.; Bakalova, R.; Higashi, T. Overproduction of reactive oxygen species-obligatory or not for induction of apoptosis by anticancer drugs. Chin. J. Cancer Res. 2016, 28, 383-396. [CrossRef]

118. Song, P.; Zhang, R.; Wang, X.; He, P.; Tan, L.; Ma, X. Dietary grape-seed procyanidins decreased postweaning diarrhea by modulating intestinal permeability and suppressing oxidative stress in rats. J. Agric. Food Chem. 2011, 59, 6227-6232. [CrossRef]

119. He, L.; He, T.; Farrar, S.; Ji, L.; Liu, T.; Ma, X. Antioxidants maintain cellular redox homeostasis by elimination of reactive oxygen species. Cell. Physiol. Biochem. 2017, 44, 532-553. [CrossRef] [PubMed]

120. Ma, X.X.; Fan, P.; Li, L.S.; Qiao, S.Y.; Zhang, G.L.; Li, D.F. Butyrate promotes the recovering of intestinal wound healing through its positive effect on the tight junctions. J. Anim. Sci. 2012, 90, 266-268. [CrossRef] [PubMed]

121. Yang, W.S.; SriRamaratnam, R.; Welsch, M.E.; Shimada, K.; Skouta, R.; Viswanathan, V.S.; Stockwell, B.R. Regulation of ferroptotic cancer cell death by GPX4. Cell 2014, 156, 317-331. [CrossRef] 
122. Yang, W.S.; Stockwell, B.R. Synthetic lethal screening identifies compounds activating iron-dependent, nonapoptotic cell death in oncogenic-RAS-harboring cancer cells. Chem. Biol. 2008, 15, 234-245. [CrossRef] [PubMed]

123. Yagoda, N.; von Rechenberg, M.; Zaganjor, E.; Bauer, A.J.; Yang, W.S.; Fridman, D.J.; Stockwell, B.R. RAS-RAF-MEK-dependent oxidative cell death involving voltage-dependent anion channels. Nature 2007, 447, 865-869. [CrossRef] [PubMed]

124. Dixon, S.J.; Lemberg, K.M.; Lamprecht, M.R.; Skouta, R.; Zaitsev, E.M.; Gleason, C.E.; Stockwell, B.R. Ferroptosis: An irondependent form of nonapoptotic cell death. Cell 2012, 149, 1060-1072. [CrossRef]

125. Prior, R.L.; Wu, X.; Schaich, K. Standardized methods for the determination of antioxidant capacity and phenolics in foods and dietary supplements. J. Agric. Food Chem. 2005, 53, 4290-4302. [CrossRef]

126. Gutteridge, J.M.; Halliwell, B. Mini-review: Oxidative stress, redox stress or redox success? Biochem. Biophys. Res. Commun. 2018, 502, 183-186. [CrossRef] [PubMed] 